\title{
An Overview on Local and Global Branded Products for Knit Apparels in Bangladesh and their effect on consumer behavior
}

\author{
Toukir Ahmed Hridoy, Md. Mazbah Uddin, Mashiur Rupak, Md. Abdullah Al Hossain, Tanvir \\ Mahady Dip, Md. Faisal Ahmed \\ 1, 2,3,4,5 Bangladesh University of Textiles,
}

92, Shaheed Tajuddin Ahmed Avenue, Tejgaon Industrial Area, Dhaka 1208

${ }^{6}$ Ahsanullah University of Science and Technology, 141 \& 142, Love Road, Tejgaon Industrial Area, Dhaka

\begin{abstract}
:
The project mainly deals with detailed study on export oriented \& local knit brands \& their products, while taking account of various aspects such as - product type, age group, construction of fabric, fabric sourcing, fabric supplier, fabric cost, FOB cost of garments, accessories sourcing \& some activities towards sustainability of brands. In this project samples are collected randomly from the merchandising departments of different company \& buying houses. Brands are selected in convenient method. We also selected some renowned local brand randomly. Quantitative data \& qualitative data are collected through some questionnaires \& then they are analyzed. The export oriented brands are selected for the study from North America, South America \& Europe region. The result visualizes the picture of detailed study on export oriented \& local knit brands \& some drawbacks of our local brand has been discovered with some recommendation of appropriate solutions. A detailed survey was also conducted to find out how different aspects of the brands affect consumer behavior.
\end{abstract}

Keywords: Brand \& Branding, Consumer \& Brand, Knitting, Export, Global \& Local Brands, Market Offerings, Stores Distribution, Unit Price, Sustainability, Sourcing, SWOT, Geography of Brands.

\section{Introduction}

Globalization is the principal and most favorite slogan of brands and businesses around the world. Globalization involves economic integration of countries. "Globalization can thus be defined as the intensification of worldwide social relations which link distant localities in such a way that local happenings are shaped by events occurring many miles away and vice versa" (1). Retail markets in developed countries such as the United States and Western Europe have already reached a maturity stage, characterized by a slow population and market saturation and less space left for new developments. Although consumers in developing countries is not highly familiar with global brands before the brands actually enter the market, they tend to become more loyal towards global brands compared to local brands because of perception of better quality. (2)
Globalization in Bangladesh broadly started with changing political plot in 1975. After the political plot, government withdrew from his predecessors' affinity with the Soviet bloc, developing closer relations with the United States, Western Europe, Africa, the Middle East, the People's Republic of China and other Islamic nations. Bangladesh opened for world and the process of privatization started after 1975. The RMG industry in Bangladesh has developed from outside pressure rather than emerging to meet local demands. The increasing wages in the clothing producing countries paved the way to establish RMG industry in Bangladesh, as the countries started looking for low-wage situation of factories. The industry is the most prominent export oriented industry of the country which has achieved very significant growth during last 25 years. Bangladesh is the second largest garment exporter in the world. In the year 2016 Bangladesh's RMG 
export was 28.668 billion USD. It is one of the biggest pillars of the economy. Government has set a goal to achieve 50 billion exports by 2021. Some experts predicted that Bangladesh will export double in the next 10 years.

\subsection{Background of the Study}

People of Bangladesh used to have more of a traditional preference for selecting their attire. For example, men wore Lungi, Panjabi, t-shirt, and Shirt and women wore Shari. With the passage of time, people are more interested to wear readymade dresses, particularly branded products. By the mid 2000's, purchase habit of customers started changing gradually, because of increasing urbanization, and changes in the social and economic status, personality and life styles. Many local apparel products brands such as Cat's Eye, Yellow, Westecs, Artisti, Aarong, Kay Kraft, Richman, Dorjibari, Anjans, Ecstasy, Plus point, Rex, Artiness etc. are trying to expand their clothing business to satisfy the local customers' demand of clothing.

However Bangladeshi local apparel brands are not yet ready to compete with the international brand. To comprehend the reasons behind this some examples may be stated, such as lack of apt fashion designers, insufficient capital, improper planning, inaccurate consumer forecasting etc.

Most of the Bangladeshi Clothing industries are export oriented. A very few clothing industries aim to serve the local market and fulfill consumers' needs and wants. But as the time goes the consumer started to think about more complex colors and design clothing, as a result complex buying behavior started which makes the fashion forecaster to think about new fashion brands and design. In this project we tried to discuss about some of Export oriented knit products of recognized global brands as well as some knit products from recognized local brands.

This research study involves global and local knit apparel products. Each brand's products have been analyzed by some specific product parameters. Perceived quality and emotional value are the two major dimensions of brand-specific association as they form critical factors in product perception. Emotional value in respect to global brands can be defined as the amount of value that relates to consumers' feeling for a certain brand (Sheth, Newman \& Gross, 1991; Barnes \& Mattsson, 2008).
Globalization gave rise to various brands, internationalization of brands has started as more and more countries opened up their economies. Brands are associated with consumer attitude; in a foreign country, this attribute plays an important role to decide the success of a certain brand. Future studies can reflect on broader study of different regions and detailed analysis of consumers. (3)

\subsection{Objectives:}

- Learning about export oriented knit products.

- Learning about the specifications of these products.

- Learning about the sourcing of the materials for these products.

- Learning about local brands \& their products.

- Learning about present condition of local knit products.

- Knit products of Bangladesh- opportunities, challenges.

\section{Literature Review}

\subsection{Branding Theory}

There are brands and logos present all around us. Branding has proven to be an essential strategy for marketing even in noncommercial organizations like political outfits and charities. It can be utilized for enhancing the profitability of actors, sports personalities, celebrities and also cities (4). Branding is considered as a separate industry which acts as a key mechanism to enable the smooth functioning of a market-oriented economy. Some brands of specific countries are considered superior to others in countries which raised the question of effect on homogenization of culture but the brands help create a working identity for a product influencing consumers' purchase intention. Brand and advertising walks in continuum with each other creating a composite industrial environment; this continued focus on advertising has given rise to a functioning cultural economy at the expense of other forms of promotion. Branding converts a certain commodity into a self-promotional form which creates an insatiable desire among consumers who want to procure it. Before delving into further discussion about brands and how they help to generate revenue for brands and corporations, we should understand the proper definitions.

2.2 Definition of Brand and Branding 
A brand is a name, term, design, symbol, or any other feature that identifies one seller's good or service as distinct from those of other sellers. The word "brand" is derived from the Old Norse brand meaning "to burn" which refers to the practice of producers burning their mark (or brand) onto their products. The concept of brands is not new but comparatively branding a brand is a product derived from the start of modern globalization at the end of the Cold War. It was actually during the 1990s, that a previously essential set of practices product design, retail design, point-of purchase marketing came together to be known as branding.

\subsection{Advantages of Branding}

Proper branding can result in higher sales of not only one product, but on other products associated with that brand (5). Some people distinguish the psychological aspect; brand associations like thoughts, feelings, perceptions, images, experiences, beliefs, attitudes, and so on that eventually become linked to the brand from the experiential aspect. The experiential aspect invariably consists of the sum of all points of contact with the brand and is known as the brand experience which is a brand's action perceived by a person. Brand experience as a concept is defined as certain sensations, feelings, cognitions, and behavioral responses evoked by brand-related stimuli which arise as part of a brand's design and identity, packaging, communications, and environments. The psychological aspect, sometimes referred to as the brand image, is a symbolic construct created within the minds of people, consisting of all the information and expectation associated with a product, service or the company that is providing them.

\subsection{Prospect from Brands}

People engaged in branding seek to align the expectations behind the brand experience, creating the impression that a brand associated with a product or service has certain qualities or characteristics that make it special or unique. A brand is therefore one of the most valuable elements in an advertising theme, as it demonstrates what the brand owner is able to offer in the marketplace. So we can posit that the art of creating and maintaining a brand is called brand management. In marketing research, seven brand management approaches have been identified during 1985-2006: the economic approach, the identity approach, the consumer-based approach, the personality approach, the relational approach, the community approach and the cultural approach.

\subsection{Attachment of Brands to Consumers}

Holding onto a consumer base has never been easy in a foreign market for a global brand in the presence of millions of local brands. For example, nowadays within a five-minute walk in majority of cities or towns, we can find at least five retail outlets selling similar merchandise each competing for space and attracting for more customer patronage. Corporations have spent billions of dollars trying to make consumers as loyal to their products and services. Ever since consumers on market research panels began weighing in on everything from baby food quality to shoe shapes, companies have tried to tailor products to meet shoppers' preferences.

More recently, as the Internet and other channels of electronic commerce became common marketresearch tools in the mid-90s, businesses have tracked what individual customers buy - and do not buy. Now, with all that information at their fingertips, executives have been trying to figure out which business practices make faithful customers loyal. Yet there is this constant dilemma about why customers stick with a brand). Today, the search for the ties that bind customers to brands has taken on fresh urgency. The branding aspect of commodities acts as an integral part of brand's sustainability. The brand is the reason why consumers associated themselves with a company that creates and sustains the attraction and desire for products. The equity markets are volatile and venture investors are chastened, so loyal customers represent a company's best prospects for pumping capital into a business which can be counted on to build a solid base of revenues as well as to expand profits

\subsection{Theory of Knitting}

Knitting is the method of creating fabric by transforming continuous strands of yarn into a series of interlocking loops, each row of such loops hanging from the one immediately preceding it.

\section{Knitted Fabric:}

Knitted fabric is a textile that results from knitting. It is more flexible than knit fabric. There are two major varieties of knit fabric:

- Warp knit fabric 
- Weft knit fabric

\section{Knit Products:}

The products which are made from knitted fabrics are called knit products.

\section{Methodology}

\subsection{Materials of the Project}

We used tech pack for the data collection of export oriented brands \& their products. We collected these tech packs from different buying houses \& companies. We designed a questionnaire for collecting information on products for global brands. We also used some questionnaires to collect data for the local brands \& their products.

\subsection{Method of the Project}

\subsubsection{Method of experiment}

We used survey method for the project work.

\subsubsection{Method of Testing or Data Collection}

We have chosen following methods:

a) Primary data: These are those data, which are collected afresh and for the first time, and thus happen to be original in character. We have used the structured questionnaires'.

b) Secondary data: These are those which have already been collected by someone else and which have already been passed through the statistical process. We collect the data from the sources like internet, published data etc.

Population of the study: This Study was conducted at Dhaka, Gazipur, and Narayangonj.

Sample Size: It is the total number of respondents targeted for collecting the data for the research. We have taken sample size of 80 respondents for our research.

Sampling Technique: Simple Random sampling technique is used in this research project

Data Analysis: We entered the daily data into MS-Excel sheets. After the exhaustion of the specified geographical area, this data has analyzed using the different inbuilt formulae of Microsoft excel this will also help us in making the simple graphical and tabulation techniques. This data will help us in analyzing the outcome of the research.

\subsubsection{The global brands and their products}

\subsubsection{Next}

\subsection{Brand Overview}

Next is a British multinational clothing, footwear and home products retailer. It's headquarter is in Enderby, Leicestershire. Next is the largest clothing retailer by sales in the United Kingdom, having overtaken Marks \& Spencer in early 2012. The company was founded by Joseph Hepworth in Leeds in 1864 as a tailor under the name of Joseph Hepworth \& Son. By 1884 the company had 100 outlets.

NEXT believes in the following strategies:

$\checkmark$ Improving and developing NEXT product ranges.

$\checkmark$ Success in which is measured by sales performance.

$\checkmark$ Profitably increasing retail selling space. (6)

\subsection{Market Offerings}

Men: Casual and formal shirts, Jacket and coat, Jeans and trousers, T-shirts and hoodies, Sweaters, Underwear.

Women: Jeans, Lingerie, Nightwear and Loungewear, Bags and Accessories, Swim and Beachwear

\subsection{Store locations}

Africa- Libya (2), Morocco (2), Egypt (1)

Asia- Saudi Arabia (23), UAE (16), Japan (14), India, Indonesia (12), Kuwait (9), Pakistan (5), Oman (3), Qatar (3), Bahrain (2), Hong Kong (1),Kazakhstan (2), Israel (1), Lebanon (1), Malaysia (1), Mongolia (1)

Europe-United Kingdom 519, Ireland 29, Russia 26, Czech Republic 8,Cyprus 5,Croatia 4,Greece 4,Malta 4,Estonia 3,Latvia 3,Romania 4,Slovakia 3,Armenia 2,Azerbaijan 2 ,Belarus 2,Georgia 2,Gibraltar 1,Iceland 1,Norway 1,Sweden 1, Kosovo 1.

Oceania- Australia, New Zealand 5

\subsection{Collected samples}

Table 1: Samples of knit products of NEXT produced in Bangladesh

\section{Results and Discussion \\ 4.1 Descriptions of Sample}




\begin{tabular}{|c|c|c|c|}
\hline Product & Polo & T-shirt & Trousers \\
\hline Age Group & Adult & Adult & Adult \\
\hline Materials & $\begin{array}{l}100 \% \\
\text { cotton } \\
220 \mathrm{~g} \\
\text { polo } \\
\text { ninwa }\end{array}$ & $\begin{array}{l}95 / 5 \\
\text { cotton/elastan } \\
\text { e }\end{array}$ & $\begin{array}{l}95 / 5 \\
\text { Cotton/Elasta } \\
\text { ne } 180 \text { GSM }\end{array}$ \\
\hline Production & Complet & Completed & Completed \\
\hline Manufacture & Huafu & Huafu & Local Boyz \\
\hline Fabric & Huafu & Huafu & DIRD \\
\hline Fabric cost & $\$ 6.50 / \mathrm{k}$ & $\$ 5.30 / \mathrm{kg}$ & $\$ 6.00 / \mathrm{kg}$ \\
\hline $\begin{array}{l}\text { Accessories } \\
\text { sourcing }\end{array}$ & R-pac & Local & Local \\
\hline $\begin{array}{l}\text { Garments } \\
\text { Cost FOB }\end{array}$ & $\begin{array}{l}\$ 8.80 / \\
\text { pcs }\end{array}$ & $\$ 3.00 / \mathrm{Pc}$ & $\$ 4.50 / \mathrm{Pc}$ \\
\hline
\end{tabular}

\subsubsection{Alexander Julian}

\section{ALEXANDER JULIAN}

\subsection{Brand Overview}

Alexander Julian is an American clothing designer widely known for his Colors Clothing Brand and designing his own $\neg$ clothing fabric. Julian is known as the thinking man's designer - an artist who is not afraid to experiment with color, texture and detail, creating smart fashion designed for the taste of a connoisseur.

In 1975 Julian moved to New York and founded the "Alexander Julian Company". This company set out to modernize traditional menswear with innovative new silhouettes and fabrics by introducing new colors and color combinations into the common vernacular.

To Alexander Julian, fashion and home furnishings are not simply functional decorations but self-expression and personal fulfillment. The mission of this company is simple - Create products that foster a sense of well-being. (7)

\subsection{Market Offering}

- Jacket, Shirt, Coat, Basketball Uniform, Blazer, Sweater.

\subsection{Store locations}

- Gene Hiller, United States

- Ascot Shop, United States

- At Ease, United States

- M. Penner, United States

- Godfrys, United States

- Hutton's, United States

\subsection{Collected samples}

Table 2: Samples of knit products of Alexander Julian produced in Bangladesh

\begin{tabular}{|l|l|l|}
\hline Product Types & T-shirt & T-shirt \\
\hline Age Group & Adult & Adult \\
\hline Materials & $\begin{array}{l}97 / 3 \\
\text { cotton/elastane }\end{array}$ & $\begin{array}{l}95 / 5 \\
\text { cotton/elastane }\end{array}$ \\
\hline Production & Completed & Completed \\
\hline Manufacturer & Local Boyz Ltd & Local Boyz Ltd \\
\hline Fabric source & Euro Tex & Euro Tex \\
\hline Fabric cost & $\$ 3.20 / \mathrm{kg}$ & $\$ 3.50 / \mathrm{kg}$ \\
\hline $\begin{array}{l}\text { Accessories } \\
\text { sourcing }\end{array}$ & Montrims & Montrims \\
\hline $\begin{array}{l}\text { Garments Cost } \\
\text { wit FOB }\end{array}$ & $\$ 2.25 / \mathrm{pcs}$ & $\$ 2.50 / \mathrm{pcs}$ \\
\hline
\end{tabular}

\subsubsection{C\&A}

\subsection{Brand Overview}

C\&A is an international chain of fashion retail clothing stores, with European head offices in Vilvoorde, Belgium, and Düsseldorf, Germany. Since its founding in August 1841, C\&A has been at the forefront of fashion. From making 'ready-towear' a thing when custom-made was the norm, to popularizing miniskirts in the $60 \mathrm{~s}$, introducing the Com-bi-kini in the 70s, Bio Cotton in early 2000 and the first Cradle-to-Cradle Gold certified garment (www.c-a.com/c2c) in 2017 - they have always evolved with the times, making stylish and quality clothes possible for everyone. It has retail stores in many European countries. It serves only the largest markets of Asia, North America and South America. C\&A's brands include Angelo Litrico, Canda, Clockhouse, Palomino, Rodeo (ski and snowboard clothes), Westbury, Yessica, Yessica Pure, and Your Sixth Sense. The core values that they believe in are:

$\checkmark$ C\&A is passionately committed for their customers

$\checkmark$ Responsibility with trust

$\checkmark$ C\&A only works as a team

$\checkmark$ Delivering together

$\checkmark$ C\&A respects people and treats them accordingly

$\checkmark$ C\&A does not accept the waste or misuse of resources

$\checkmark$ Continuous commitment (8)

\subsection{Market Offering}

Jackets and coats, Shirt, t-shirts, polo shirts , Pants and trousers, Sweater and cardigans, Skirts, Pajamas and nightgowns, Underwear etc. 


\subsection{Store locations}

\section{Asia- China 84}

Europe- Austria 124, Switzerland 99, Poland 65, Czech Republic 42, Romania 38, Hungary 36, Slovakia 16, Slovenia 15, Russia 11, Spain 99, Portugal 34, Croatia 20, Italy 16, Serbia 15, France 169, Belgium 138, Netherlands 124, Luxembourg 10, Sweden 1, Kosovo 1

North America- Mexico 75

South America- Brazil 297

\subsection{Sustainability}

The main strategy is to make sustainability mainstream to become the new normal. They want their customers to trust them to do the right thing, so they can buy their products without having to worry about how they were made. C\&A works on their sustainability to focus on areas that are most relevant for their business and where they can have the biggest impact - (9). They are taking approaches regarding sustainable products, sustainable supply, sustainable lives.

\subsection{Collected samples}

Table 3: Samples of knit products of C\&A produced in Bangladesh

\begin{tabular}{|l|l|l|l|}
\hline Product Types & Nightwear & Polo Shirt & T-shirt \\
\hline Age Group & Adult & Adult & Adult \\
\hline Materials & $\begin{array}{l}\text { S/J } 140 \\
\text { GSM }\end{array}$ & $\begin{array}{l}100 \% \\
\text { cotton 230g } \\
\text { polo pique }\end{array}$ & $\begin{array}{l}\text { S/J Go\% cotton } \\
\text { GSM }\end{array}$ \\
\hline Production & Completed & Completed & Completed \\
\hline Manufacturer & Comfit & Comfit & Comfit \\
\hline Fabric source & Comfit & Comfit & Comfit \\
\hline Fabric cost & $6.5 \$ / \mathrm{KG}$ & $8.00 \$ / \mathrm{KG}$ & $3.30 \$ / \mathrm{KG}$ \\
\hline $\begin{array}{l}\text { Accessories } \\
\text { sourcing }\end{array}$ & local & local & local \\
\hline $\begin{array}{l}\text { Garments } \\
\text { Cost with } \\
\text { FOB }\end{array}$ & $\$ 6.00 / \mathrm{Pc}$ & $\$ 7.00 / \mathrm{Pc}$ & $\$ 2.50 / \mathrm{Pc}$ \\
\hline
\end{tabular}

\subsubsection{Cencosud}

\subsubsection{Brand Overview}

Cencosud S.A. is a publicly traded multinational retail company. It's the largest retail company in Chile and the third largest listed retail company in Latin America, competing with the Brazilian Companhia Brasileira de Distribuição and the Mexican Walmart de México y Centroamérica as one of the largest retail companies in the region. The company has more than 1045 stores in Latin
America. It has more than 4.3 million active credit card accounts, issued under the brand Tarjeta Cencosud, Tarjeta Cencosud Colpatria (Colombia) and Cartão Cencosud Bradesco (Brazil).

\subsection{Mission of Cencosud}

"Our mission is to work day by day, to become the most profitable and prestigious retailer in Latin America, based on excellence in our quality of service, respect for the communities in which we live and our commitment team of collaborators." (10)

\subsection{Location}

Cencosud operate through a number of formats, including supermarkets, home improvement stores, shopping centers and department stores. They are headquartered in Chile and have operations in Chile and Argentina, markets in which Cencosud started and consolidated its leadership position, to continue its expansion to Brazil, Colombia and Peru.

\subsection{Collected samples}

Table 4: Samples of knit products of Cencosud produced in Bangladesh

\begin{tabular}{|l|l|l|l|}
\hline Product & T-shirt & Pajama & T-shirt \\
\hline Age Group & Adult & Adult & Adult \\
\hline Materials & $\begin{array}{l}100 \% \\
\text { cotton }\end{array}$ & $\begin{array}{l}\text { S/J } \\
\text { GSM160 }\end{array}$ & $\begin{array}{l}\text { Single } \\
\text { jersey, } \\
100 \%\end{array}$ \\
\hline Production & Completed & Completed & Completed \\
\hline Manufacture & Fine Tex & R.N & R.N \\
\hline Fabric source & Fine Tex & R.N & R.N \\
\hline Fabric cost & 5 \$/KG & $5.5 \$ / K G$ & $4.5 \$ / K G$ \\
\hline $\begin{array}{l}\text { Accessories } \\
\text { sourcing }\end{array}$ & local & local & local \\
\hline $\begin{array}{l}\text { Garments } \\
\text { Cost with } \\
\text { FOB }\end{array}$ & $\$ 1.7 / \mathrm{Pc}$ & $\$ 3.5 / \mathrm{Pc}$ & $\$ 2.5 / \mathrm{Pc}$ \\
\hline
\end{tabular}

\subsubsection{Victoria Secret}

\subsection{Brand Overview}

Victoria's Secret is an American designer, manufacturer, and marketer of women's premium lingerie, women's wear, and beauty products. It is the largest American retailer of women's lingerie and a subsidiary of L Brands. It was founded in 1977 by Roy Raymond and his wife Gaye. From its founding to the early 1980 's, the company grew to 5 stores and a successful catalog. The mission statement for Victoria's secret retail chain is committed to building the world's best fashion 
brands offering captivating customer experiences that drive long-term loyalty and deliver sustained growth for the shareholders. (11)

\subsection{Market Offering}

Sport Bras, T-shirt, Bikinis, Thongs and v-strings, Tops, Sleep shirts, Pajamas, Cosmetic Bags

\subsection{Store Locations}

United States, Canada, United Kingdom

\subsection{Sustainability}

Victoria's Secret has achieved the E-label. This is the lowest possible sustainability score. But in recent times it aimed to eliminate sources of wood pulp, used to make rayon, viscose and modal that contribute to rainforest destruction or violate the rights of local people. The company committed to investigate its supply chain for products from destructive regions and stop using those sources by the end of 2017 .

\subsection{Collected samples}

Table 5: Samples of knit products of Victoria's Secret produced in Bangladesh

\begin{tabular}{|l|l|l|}
\hline Product Types & Athletic Bralette & Tank top \\
\hline Age Group & Adult & Adult \\
\hline Materials & $\begin{array}{l}100 \% \text { cotton, } \\
\text { nylon,lycra mesh }\end{array}$ & S/J GSM 140 \\
\hline Production status & Completed & Completed \\
\hline Manufacturer & Regina Miracle & D.K. Garments \\
\hline Fabric source & China & Local \\
\hline Fabric cost & $\$ 8.50 / \mathrm{kg}$ & 6 \$KG \\
\hline $\begin{array}{l}\text { Accessories } \\
\text { sourcing }\end{array}$ & SML & Local \\
\hline $\begin{array}{l}\text { Garments Cost } \\
\text { with FOB }\end{array}$ & $\$ 12.20 / \mathrm{pcs}$ & $\$ 4 / \mathrm{Pc}$ \\
\hline
\end{tabular}

\subsubsection{Kmart}

\subsection{Brand Overview}

Kmart Corporation simply known as Kmart is an American department store chain. It's headquarter is in Hoffman Estates, Illinois, United States. The company known as Kmart was incorporated in 1916 while the first Kmart named store did not open its doors until 1962. The founder of the company is Frank Winfield Woolworth.

Kmart believes in -

$\checkmark$ Ensuring the quality and safety of the products. $\checkmark$ Sourcing the products ethically.

$\checkmark$ Creating a high performance culture.

$\checkmark$ Strengthening communities. (12)

\subsection{Market Offerings}

Men: Shirts, Jeans, Coats and Jackets, Socks, Underwear

Women: Tops, Dresses, Jeans, Coats and Jackets, Lingerie

Kids: Bodysuits, Sleepwear, Sets

\subsection{Store Locations}

Alabama, Arizona, Arkansas, California, Colorado, Connecticut, Delaware, Florida, Georgia, Guam, Hawaii, Idaho, Illinois, Indiana, Iowa, Kansas, Kentucky, Louisiana, Maine, Maryland, Massachusetts, Michigan, Minnesota, Mississippi, Missouri, Montana, Nebraska.

\subsection{Environmental Concern}

On May 9, 2007, Kmart was penalized \$102,422 (equivalent to $\$ 121$ thousand in 2018) for violations of federal hazardous waste, clean water, emergency planning and preparation regulations at 17 distribution centers. Kmart corrected the violations by preparing and implementing spill prevention control and countermeasure plans, applying for appropriate storm water permits, complying with hazardous waste generator requirements, and submitting reports to state and local emergency planning and response organizations informing them of the presence of hazardous substances. (13)

\subsection{Collected samples}

Table 6: Samples of knit products of Kmart produced in Bangladesh

\begin{tabular}{|l|l|l|l|}
\hline Product & Uniform & Pajama & T-shirt \\
\hline Age Group & Adult & Adult & Adult \\
\hline Materials & $\begin{array}{l}60 / 40 \quad \text { CVC } \\
200 \quad \text { GSM } \\
\text { Pique }\end{array}$ & $\begin{array}{l}\text { S/J GSM } \\
160\end{array}$ & $\begin{array}{l}100 \% \\
\text { Cotton S/J } \\
\text { GSM 150 }\end{array}$ \\
\hline Production & Completed & Completed & Completed \\
\hline Manufacturer & Renaissance & D.K. & Local Boyz \\
\hline Fabric source & Local & R.N Knitex & Local \\
\hline Fabric cost & $\$ 5.77 / \mathrm{kg}$ & $\$ 5.5 / \mathrm{KG}$ & $3.35 \$ / \mathrm{kg}$ \\
\hline $\begin{array}{l}\text { Accessories } \\
\text { sourcing }\end{array}$ & Local & Local & Local \\
\hline $\begin{array}{l}\text { Garments } \\
\text { Cost } \\
\text { with FOB }\end{array}$ & $\$ 2.40 / \mathrm{pcs}$ & $\$ 3.50 / \mathrm{pcs}$ & $\$ 2.80 / \mathrm{pcs}$ \\
\hline
\end{tabular}




\subsubsection{Sainsbury's:}

\subsection{Brand Overview}

Sainsbury's is the second largest chain of supermarkets in the United Kingdom with a $16.9 \%$ share of the supermarket sector in the United Kingdom. It was founded in 1869 by John James Sainsbury with a shop in Drury Lane, London. The company became the largest grocery retailer in 1922. (14) Sainsbury's believes in following strategies:

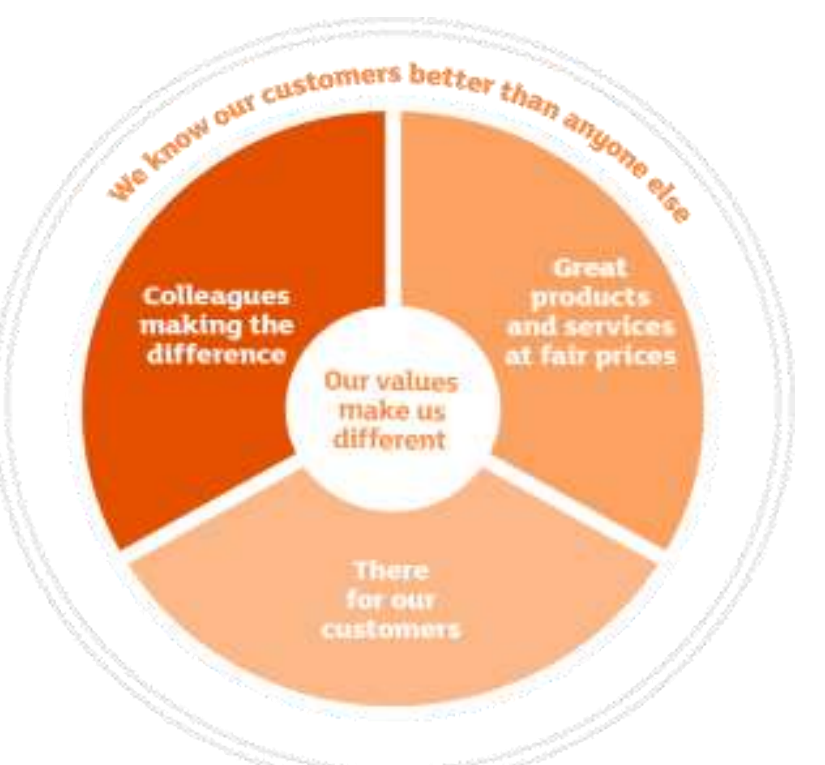

\subsection{Market Offerings}

Men: Casual Shirts, Formal Shirts, T-shirts, Coats and Jackets, Hoodies and Sweatshirts, Shorts, Jeans

Women: Leggings, Skirts, Tops and Tunics, Jumpers and Cardigans, Sportswear and Joggers
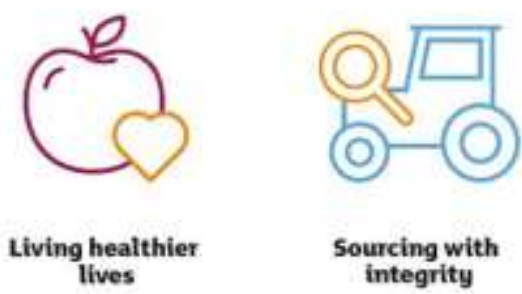

Living healthier lives
Kids: Nightwear and Slippers, Jumpers, Swimwear, Skirts

\subsection{Stores}

In June 2015 Sainsbury's store portfolio was as follows-

\section{Format $\quad \underline{\text { Number }}$ Total Space (sq ft)}

Supermarkets $598 \quad 21,190,000$

Convenience $714 \quad 1,629,000$

stores

Total $\quad 1312 \quad 22,819,000$

The Regional distribution centers are given below:

- Basingstoke, Hampshire

- Belfast, Northern Ireland

- Dartford, Kent

- Emerald Park, Emerson's Green, Bristol

- Greenford, Middlesex

- Vauxhall, Nine Elms (London SW8)

- Hams Hall, Coleshill, West Midlands

- Haydock, St Helens, Merseyside

- Langlands Park, East Kilbride, South Lanarkshire

- Northampton, Northamptonshire

- Waltham Point, Essex

\subsection{Sustainability}

Since 1869 , Sainsbury has always a strong sense of social, environmental and economic responsibility. All the choices they make, reflect their 5 values- (15)

\subsection{Collected samples}

Table 7: Samples of knit products of Sainsbury's produced in Bangladesh

\begin{tabular}{|l|l|l|}
\hline Product Types & T-Shirt & Polo Shirt \\
\hline Age Group & Kids & Adult \\
\hline Materials & $100 \%$ cotton S/J & $100 \% \quad$ Cotton \\
\hline Production status & Completed & Completed \\
\hline Manufacturer & Dird & D.K. Garments \\
\hline Fabric source & Dird & D.K. Garments \\
\hline Fabric cost & $\$ 6.50 / \mathrm{kg}$ & $\$ 5.70 / \mathrm{kg}$ \\
\hline
\end{tabular}

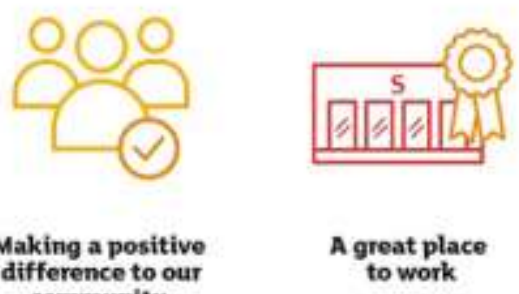

\begin{tabular}{|l|l|l|}
\hline $\begin{array}{l}\text { Accessories } \\
\text { sourcing }\end{array}$ & Local & R-pac \\
\hline $\begin{array}{l}\text { Garments Cost } \\
\text { with FOB }\end{array}$ & $\$ 2.00 / \mathrm{PC}$ & $\$ 4.80 / \mathrm{pc}$ \\
\hline
\end{tabular}

4.1.1.8 M\&Co.

\subsection{Company Overview}

M\&Co. is a Scottish chain store selling women's, men's, and children's clothes, as well as small homeware products. Its head office is in Inchinnan, Renfrewshire though its main buying 
office is in London. Previously, its head office was at Caledonia House in Paisley. Established in 1834, the company has been selling clothing for over 50 years. The chain operates over 300 stores and also has an online presence. Their current chain has grown organically from a small family business of just 6 stores and now amounts to almost 300. Between 2005 and 2007, the store portfolio was expanded and upgraded, and Mackays successfully re-branded to the more contemporary M\&Co fascia.

\subsection{Mission}

"The local department store delivering contemporary product in a compelling store environment, where service and quality are paramount." (16)

\subsection{Market Offerings}

Blouse \& shirts, Coats and Jackets, Dresses, Jumpsuits, Knitwear, Shoes, Skirts, Trousers and leggings, Tops, Lingerie

\subsection{Stores}

The chain operates over 300 stores and also has an online presence.

\subsection{Collected samples}

Table 8: Samples of knit products of M\&Co's produced in Bangladesh

\begin{tabular}{|c|c|c|}
\hline Product Types & Top (ladies) & Leggings \\
\hline Age Group & Adult & Adult \\
\hline Materials & $\begin{array}{l}\text { 100\% cotton } \\
\text { S/J 160 GSM }\end{array}$ & S/J 160 GSM \\
\hline Production status & Completed & Completed \\
\hline Manufacturer & Crossline Knit & Crossline $\quad$ Knit \\
\hline Fabric source & Crossline Knit & Crossline $\quad$ Knit \\
\hline Fabric cost & $\$ 5.00 / \mathrm{kg}$ & $\$ 4.50 / \mathrm{kg}$ \\
\hline $\begin{array}{l}\text { Accessories } \\
\text { sourcing }\end{array}$ & Local & Local \\
\hline $\begin{array}{l}\text { Garments Cost with } \\
\text { FOB }\end{array}$ & $\$ 2.30 / \mathrm{PC}$ & $\$ 2.20 / \mathrm{pc}$ \\
\hline
\end{tabular}

\subsubsection{Cotton On}

\subsection{Company Overview:}

Cotton On is an Australian retail chain, known for its fast-fashion clothing for men, women, teenagers and children. It has almost 1500 stores in 12 countries and employs 17,000 staff in Australia and internationally. Cotton On was founded in 1991, with the first store being opened in Geelong, Australia. In 2013, Cotton On acquired Australian fast-fashion brand Supré and plans to expand the brand internationally.

While they are proud of what they have achieved to date, they know they're on a continuous road to improvement. Cotton On aims to make right and meaningful decisions at every turn - not just because it's the best way of doing business but because it's simply the right thing to do. (17)

\subsection{Market Offerings:}

Men: Casual and formal shirts, Jacket and coat, Jeans and trousers, T-shirts and hoodies, Sweaters, Underwear

Women: Jeans, Lingerie, Nightwear and Loungewear, Bags and Accessories, Swim and Beachwear

Kids: Pants and leggings, Tops and T-shirts, Jackets and Vests, Hoodies and Jumpers

\subsection{Store Locations}

America- Brazil, United States

Asia- Malaysia, Singapore, Hong Kong, South Korea, Japan, China, Philippines, Thailand, Indonesia

Middle East and Africa- United Arab Emirates, Lebanon, Oman, South Africa

Europe- Germany, Poland, Switzerland, Netherlands, Norway, Italy, France, Ireland, Turkey, Sweden, Russia, Ukraine, Belgium

Oceania- Australia, New Zealand

\subsection{Sustainability}

Some ethical commitments of Cotton On Group are given below:

- The environments in which our products are made and the materials used to make them are incredibly important to us.

- We aim to provide our customers with the products they want at the right price, while ensuring these products are designed in line with the cultural values and legal requirements of the countries in which we operate.

- Our Ethical Sourcing Program includes various initiatives that are geared towards preserving water, reducing waste and conserving energy, all while ensuring we have a positive social and economic impact on communities around the world. 


\subsection{Collected samples}

Table 9: Samples of knit products of Cotton On produced in Bangladesh

\begin{tabular}{|l|l|}
\hline Product Types & Polo-shirt \\
\hline Age Group & Kids \\
\hline Materials & $95 / 5$ cotton/elastane \\
\hline Production status & Completed \\
\hline Manufacturer & Local Boyz Ltd \\
\hline Fabric source & Euro Tex \\
\hline Fabric cost & $\$ 4.70 / \mathrm{kg}$ \\
\hline Accessories sourcing & Nexin \\
\hline
\end{tabular}

\section{Strategic Priorities}

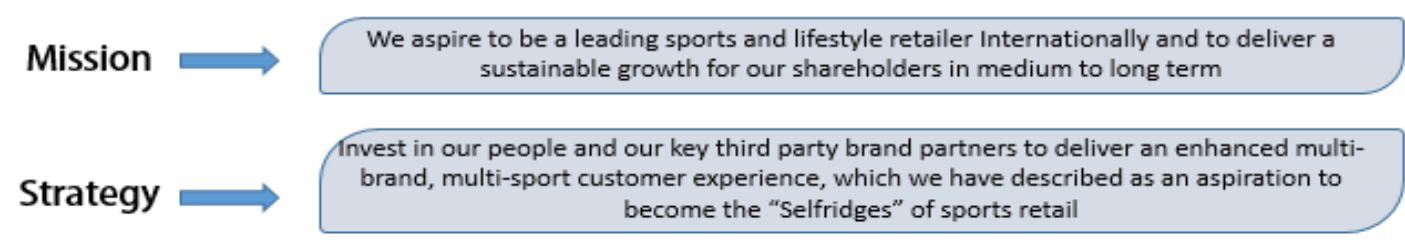

Strategic Priorities

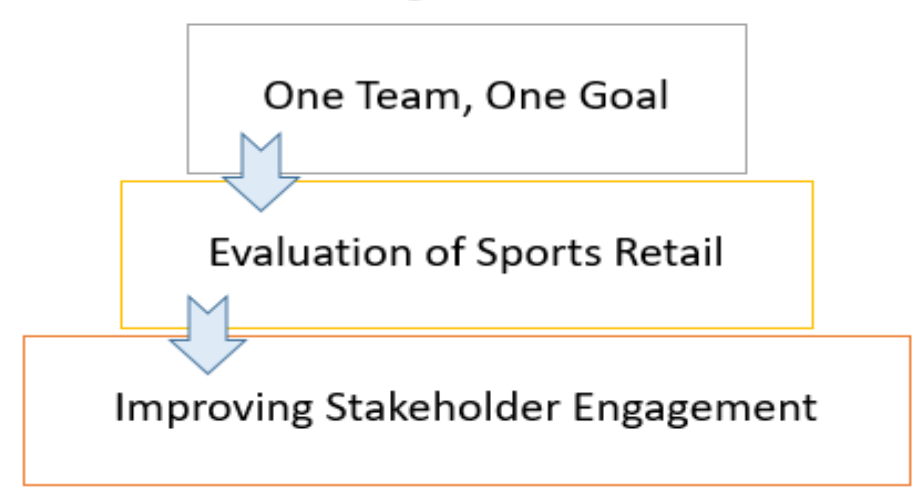

Fig 1: Mission and Strategic priorities of SPORTS DIRECT

\subsection{Market Offerings:}

Men: Shoes, Boots,Hi Tops,Hoodies

Ladies: Flip flop, Canvas Shoes, Wellies

\subsection{Stores:}

Wisbech SD, Surrey Quays, Lillywhites, Oxford Street, Friern Barnet

\subsection{Sustainability:}

Health and Safety: They regularly review their procedures to ensure robust safety management.

Environment: They are committed to reducing impact their business has on the environment, now and in the future.

\subsubsection{Sports Direct:}

\subsubsection{Brand Overview:}

Sports Direct is a British retailing group. It was established in 1982 by Mike Ashley. This company is the United Kingdom's largest sportsgoods retailer and operates roughly 670 stores worldwide. The company was founded by Mike Ashley in 1982 as a single store in Maidenhead trading under the name of Mike Ashley Sports. (18) 


\begin{tabular}{|l|l|l|l|}
\hline Fabric cost & $\$ 3.35 / \mathrm{kg}$ & $\$ 3.80 / \mathrm{kg}$ & $\$ 6.50 / \mathrm{kg}$ \\
\hline $\begin{array}{l}\text { Accessories } \\
\text { sourcing }\end{array}$ & Paxer & R-pac & Paxer \\
\hline $\begin{array}{l}\text { Garments } \\
\text { Cost } \\
\text { with FOB }\end{array}$ & $\$ 2.80 / \mathrm{pcs}$ & $\$ 2.75 / \mathrm{pc}$ & $\$ 8.50 / \mathrm{pc}$ \\
\hline
\end{tabular}

\subsubsection{The local brands and their products}

\subsubsection{YELLOW}

Yellow is a Bangladesh-based fashion brand and clothing retailer owned by Beximco. Its corporate headquarters is located at Beximco Industrial Park, Dhaka, Bangladesh. Yellow started their journey in 2004 and now they have 15 outlets across Bangladesh and Pakistan including a 24/7 online store. (19)

\subsection{Key values \& features}

- Design-driven brand with superior quality

- Modern interpretation of fashion but comfortable

- Believes in innovation

- Wide range of fashion clothing for women, men and even children.

- Inspired by their customer.

- Unconventional yet high quality

- Progressive yet tastefully casual-yellow embraces harmony through conflict

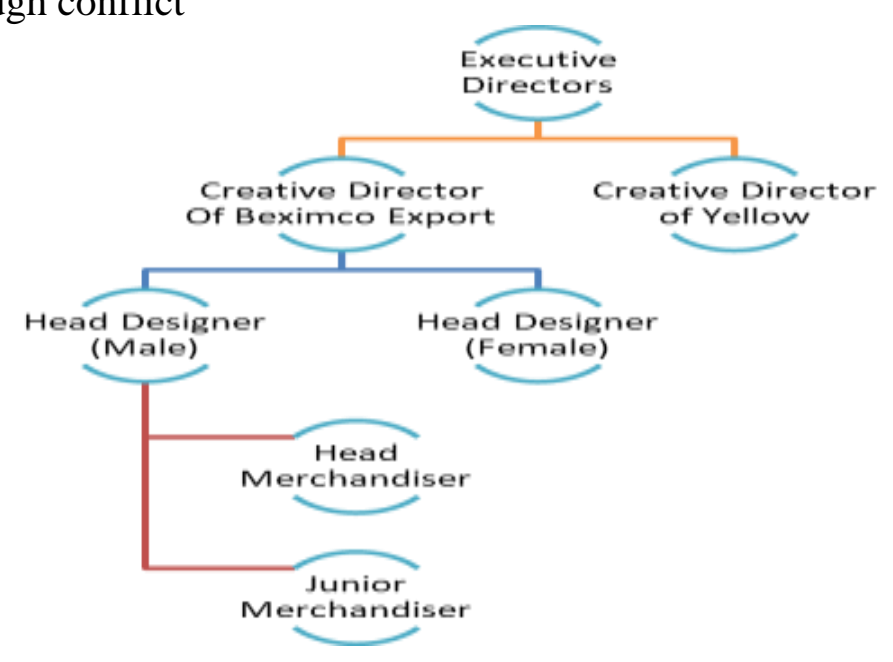

\subsection{Market Offering}

Product line includes a wide range of fashion clothing, fragrance, and accessories for men, women and children; textiles for home decoration; avant-garde ceramic items; paintings; books; and many more.

\section{YELLOW Men}

Casual Shirts, Templeton Shirts, Formal Shirts, Polos, Tees, Punjabi, Jackets And Blazers, Sweaters, Hoodies, Denim, Casual Pants

\section{YELLOW Women}

Ethnic Tops, Fashion Tops and Shirts, Tees, Denim and Trousers, Jackets \& Blazers, Sweaters, Lawn, Saree

\section{YELLOW Beximco Luxury Lawn}

Beximco Luxury Lawn was launched in 2014 by Beximco, dedicated only to Women's clothing.

\subsection{Internal Environment}

$\checkmark$ Follows divisional structure

$\checkmark$ Yellow designing divided in two parts - male and female clothing

\subsection{Hierarchy}

Fig 2: Operational Network Organogram of Yellow

\subsection{Outlets / Stores: \\ Bangladesh}

Bailey Road, Bashundhara City, Dhanmondi, Maghbazar, Mohammadpur, Gulshan, Uttara (2 outlets), Wari, Chittagong, Jamuna Future Park, Banani, Mirpur

\section{Pakistan:}

Zamzama Boulevard, Karachi, Dolmen Mall, Tariq Road, Karachi, Dolmen City Mall Clifton, Karachi, M.M. Alam Road, Lahore

\subsection{Competitor}

local brands and these are main competitors of YELLOW .They also know latest trends and tastes of customers. The 
information on market offerings and the store location has been collected from the Dhanmondi There are a lot of well-known brands such as Aarong, Easy, Artiste, Sadakalo, Ecstasy, Anjan's, outlet of Yellow.

Sailor, Cats eye, Deshal, Rang, Kay Kraft and Freeland etc. These all are

\subsection{SOWT Analysis: \\ Table 11: SWOT analysis of Aarong}

\begin{tabular}{|c|c|}
\hline Strength & Weakness \\
\hline $\begin{array}{l}\text { - Prominent brand image } \\
\text { - Well-developed infrastructure } \\
\text { - Reputed for its superior quality } \\
\text { - Has been in the market for } 10 \text { years } \\
\text { - Strong group of loyal customers } \\
\text { - Experience of long term business } \\
\text { - Wide variety of products } \\
\text { - Materials sourced from Beximco textile } \\
\text { - Trendy and fashionable }\end{array}$ & $\begin{array}{l}\text { - Marketing is not strong in international } \\
\text { branches } \\
\text { - Less variations in design } \\
\text { - Unable to open shops in all location in } \\
\text { Bangladesh } \\
\text { - Price is high } \\
\text { - No aggression in marketing strategy } \\
\text { - Lack of access to key distribution channel } \\
\text { - Lack of patent protection }\end{array}$ \\
\hline Opportunities & Threats \\
\hline $\begin{array}{l}\text { - Online Retail and E-commerce } \\
\text { - Expansion into other countries } \\
\text { - Exposure in social media } \\
\text { - Technological advancement } \\
\text { - Arrival of new technologies } \\
\text { - loosen of regulation }\end{array}$ & $\begin{array}{l}\text { - Unstable political situation of Bangladesh } \\
\text { - Entry of several foreign famous brands } \\
\text { - Consumer switching is on a high rate } \\
\text { - Sift in customer tastes } \\
\text { - New regulation } \\
\text { - Increased trade barriers }\end{array}$ \\
\hline
\end{tabular}

\subsubsection{Aarong}

BRAC observed that women in Bangladesh were increasingly involved in agricultural activities. It also recognized that it was the male members of families who marketed the crops and reaped the profits, even though women completed about 75 percent of the agricultural work. In order to create an alternative opportunity to earn an income for these women and contribute to the development of a skilled workforce, BRAC established its sericulture project in 1978 under the leadership of the late Ayesha Abed, former executive assistant director of BRAC. The sericulture project has supported women in the rural areas of Manikganj in producing high quality silk, and women in rural communities of Jamalpur in producing traditional hand-stitched nakshikantha. However, it soon became apparent that the women producing the silk and nakshikantha did not have sufficient buyers for their products, nor were there any stable platforms for them to market their items. Seeing the opportunity that lay in the challenge, BRAC took the initiative to create a platform so that these women could sell their products to the urban market. Thus, Aarong was launched in 1978, creating a linkage between the rural poor and urban retailers. Since its inception "Aarong" has been working towards BRAC's mission of poverty alleviation through economic development and human capacity building, with a specific focus on the empowerment of women. The retail process follows several steps: first, a design team conceptualizes the season's motives which are then sent to the rural artisans for production. "Aarong" continuously develops the artisans' skills through training programs, and conducts quality control of the completed items before they are bought at a fair price and then sold across retail outlets in urban markets. By evolving the traditional retail process, "Aarong" strives to provide a uniquely Bangladeshi lifestyle experience while encouraging social change. A newly generated demand for Bangladeshi handcrafted products illustrates that "Aarong" has achieved this vision, and continues to challenge the retail industry with its sustainable fashion 'revolution'. (20)

\subsection{Key values \& Features}

Integrity, Inclusive, Innovative, Effectiveness

\subsection{Market Offering}

Aarong's market offerings are shaped up for its target groups like men, women, children and 
youth. Their product line is around ninety to hundred. Aarong offers ethnic wear to beautiful crafts from anarray of hand-knit textiles such as silk, cotton, handspun, endi to terracotta, bamboo, jute and much more.

Women: Traditional Sarees like Jamdani, Muslin, Fotua, Shalwar Kamiz, Fabrics, Shoes, Sandals

Man: Traditional Panjabi, Executive Shirt, Fotua, Short Kurta, T-shirt, Shawls, Sandals

Youth: Taga- A Brand of young generation Skirt, Fotua, Kurta

\subsection{Operational Network Organogram}

Aarong operation network starts from the production of the different products which are sold in the retail outlets. The products are produced under foundation for production and assembling named Ayesha Abed Foundation. Ayesha Abed Foundation are situated in Baniachong, Gorpara, Jamalpur, Jessore, Kushtia, Manikganj, Rajbari, Sherpur, Pabna, Pallobi, Kurigram, Nilphamari, Jhenaidah having 653 sub centers across Bangladesh. More than forty thousand of the total women of Aarong producers work directly for Aarong in these 13 production centers in and Twenty five thousand independent cooperative groups and traditional family-based artisans also market their crafts through Aarong. Potters, Brass Workers, Jewelers, Jute workers, Basket Weavers, Handloom Weavers, Silk Weavers, Wood Carvers, Leather workers and various artisans with specialized skills from all over the country come to Aarong for marketing and support services (aarong.com).

After the collection of the products and arrival in the outlets consumers can buy the products from the retailed outlets. This is how the collection and selling of the product goes on. The operations in the outlets are mainly carried by the managers of the outlets. They mainly are responsible to manage the outlet inventories, product sells, customer services, payment collections and personnel management. They supervise the outlet's performance and are directly responsible to report the Chief Cooperative Officer of Retail and Infrastructure for any kind of operation takes place. The Organogram of the operation network of outlets is given below:

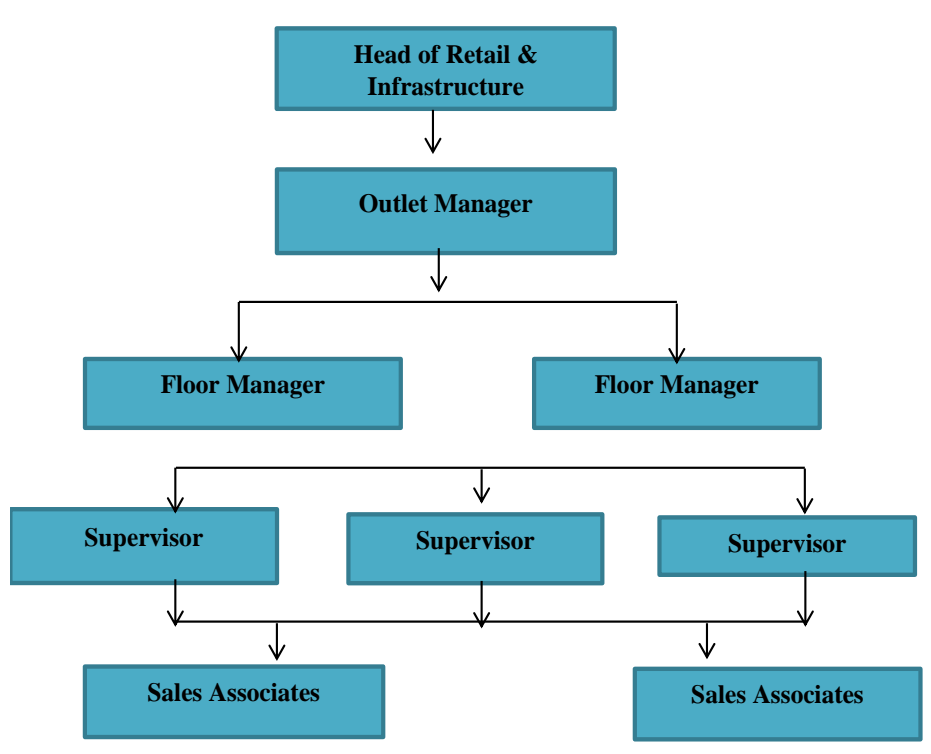

Fig 3: Operational Network Organogram of Aarong

\subsection{Outlets of Aarong}

The list of the "Aarong" outlets across the country is given below:

1978- Shurabad Road, Dhaka (Closed), 1983- Nasirabad, Chittagong, 1984- Moghbazar, Dhaka, 1985- Sylhet town, Sylhet , 1989- Lalmatia, Dhaka, 1995- Khulna town, Khulna , 1997- Gulshan, Dhaka, 1998- Rankin Street, Dhaka ,2001- Uttara Dhaka, (Reopened as flagship outlet in 2011), 2008- Halishahar, Chittagong, 2010- Mirpur, Dhaka , 2012- Comilla town, Comilla , 2013- Narayanganj,

2014- Jamuna Future Park, Dhaka , 2015- Dhanmondi, Dhaka, 2015- Banani, Dhaka , 2016-Basabo, Dhaka

\subsection{Competitors}

Currently Aarong has 5 major competitors:

- Sada Kalo, Kaycraft, Anjons, Rong, Handibazar

\subsection{SOWT analysis}

Table 12: SWOT analysis of Aarong 
- Strong brand image

- Reputed for traditional wear

- $68 \%$ of the total market share for handicrafts

- Has been in the market for 30 years, experience of long term business

- Strong group of loyal customers

- Extensive range of products

- Good customer service

- Strong marketing approach
- Expensive

- Website is not updated

- Unable to open shops in all location in Bangladesh

- Customer service can be improved

\section{Opportunities}

- Opportunity of expanding outside Bangladesh

- Can attract more customers using their brand value

- Exposure in social media

- Eco friendly operations may give them positive image

\subsubsection{Ecstasy}

\subsection{Overview}

From its humble beginnings as a single store chain in 1997, Ecstasy has quickly become one of the nation's largest fashion retailers. Ecstasy lifestyle store offers quality, exclusive and trendy merchandise to their customers. The store houses Ecstasy's Top-of the-line brand "Tanjim" for men and "Zarzain" for women along with other international brands. (21)

\subsection{Key Values \& Features:}

- Trend oriented

- Innovative and edgy design

- Focus on clothing habit of popular culture

- Cotton based products

- Glamorous products

\subsection{Market Offering}

Product line includes a wide range of Men's Apparel, Women's Apparel, Kid's Apparel, Accessories and Cosmetics etc.

Men's wear: T-shirts, Casual and dress shirts, Trousers and dress pants, Polo shirts, Summer blazer, Tanjim jeans, Tanjim shorts, Shoes \& sandals, Sports t-shirt

Women's wear: Party/dress wears, Joggers \& plazzo, Tops, Jumpsuits/rompers, Jeans/jeggings/ trousers, Shoes, Perfumes, Sunglasses

\subsection{Outlets}

- Basundhara City - (Level 2, 3 and 7), Pink City - D-17/A, 3rd floor, Pink City, Gulshan,
Threats

- Other brands promoting traditional wears

- Sift in customer tastes

- Similarities in design

Jamuna Future Park - shop-15,16,17 Zone-C, 1st floor

- Jamuna Future Park - shop-01-02 Zone-C, 1st floor,Jamuna Future Park - shop-005, Zone-C, Ground floor, Dhanmondi - House 42, Road 2/A, Dhanmondi, Dhanmondi - Plaza A.R, Shop \# 214, House \# 2, Road \# 14, Dhanmondi, Dhaka, Dhanmondi - Rangs Aman Plaza, Dhanmondi, Gulshan - Rupayon Tower, Gulshan, Uttara - 6. H-17, R-2, Sec-3, Singapore Plaza, Uttara, Uttara - RAK Tower Jashimuddin Road, Uttara., Shantinagar 41/C, Chamelibag, Shantinagar, Shantinagar 148, Shantinagar, Wari - 15, Ranking Street, Wari, Mirpur - h-2/A, R: 4, Block A, Section 6, Mirpur 10, Chittagong - 1147/A West nasirabad, IFCO Complex, Chittagong, Chittagong - 320 Amin Centre, Lalkhan bazaar, Chittagong, Khulna - Plot A- 59, KDA Mozid Shoroni, Shebbaro More, Shonadanga, Khulna, Sylhet - 19/A, Kumarpara, Ground Floor, Sylhet.

\subsection{Competitors}

Yellow, Cats Eye, Le Reve etc.

\subsection{SWOT Analysis}


Table 13: SWOT analysis of Ecstasy

\begin{tabular}{|c|c|}
\hline Strength & Weakness \\
\hline $\begin{array}{l}\text { - Strong brand image } \\
\text { - Reputed for its glamorous clothing } \\
\text { - Has been in the market for } 20 \text { years } \\
\text { - Experience of long term business } \\
\text { - Trendy and fashionable } \\
\text { - Compatible with international brands } \\
\text { - Varity of design }\end{array}$ & $\begin{array}{l}\text { - Marketing strategy is not adequate } \\
\text { - Unable to open shops in all location in } \\
\text { Bangladesh } \\
\text { - Price is high } \\
\text { - Not available for all sizes } \\
\text { - Lack of access to key distribution channel }\end{array}$ \\
\hline Opportunities & Threats \\
\hline $\begin{array}{l}\text { - Online Retail and E-commerce } \\
\text { - Expansion into other countries } \\
\text { - Exposure in social media } \\
\text { - Technological advancement } \\
\text { - Arrival of new technologies } \\
\text { - Attracting the youth who prefers trendy } \\
\text { outlook }\end{array}$ & $\begin{array}{l}\text { - Unstable political situation of Bangladesh } \\
\text { - Entry of several foreign famous brands } \\
\text { - Consumer switching is on a high rate } \\
\text { - Sift in customer tastes }\end{array}$ \\
\hline
\end{tabular}

\subsubsection{Cats Eye}

\subsection{Overview}

Cats Eye is the pioneer of the men's fashion industry since 1980 and steadily established itself to be the strongest

player in the fashion industry. It is the parent company of Monsoon Rain and Unlimited. Cats Eye recently received ISO-2000 certification for the quality of its product and design. The company has $17 \%$ of the total market share of the men's fashion industry. Cats Eye's target market consists of the upper middle class and the upper class. Company Background In 1980, Cats Eye began their journey in the form of a small shop in Green Super Market that sold all most everything from candies to ornaments.

The founders, Mr. Sayeed Siddiqui Rumi and Mrs. Ashrafun Siddiqui Dora, had kept a small part of that shop for shirts that they designed by themselves. They got a good response from the enthusiastic young men of Dhaka. Therefore, Mrs. Ashrafun Siddiqui decided that they would only sell designer clothes for men. In 1983, the couple rented a floor space in Mansur Bhaban, Elephant Road. That was the official inception of Cats Eye in the form of a small family business. Profile of the Organization After 25 successful years, today Cats Eye consists of three men's fashion brands, 29 outlets; own manufacturing plant, production capacity of 1500 units per day, 550 employees \& a brand image engraved in consumer's mind. Cats Eye stands as a creative image-

maker, marketing and designing under its own label. The mission that leads this company is "To create a style statement that suits the discerning individual. (22)

\subsection{Brand Values}

a. Brand Performance: Cats Eye's mission is to create a style statement that suits the discerning individual, while keeping a stringent eye on quality yet being affordable. The unique styles are created based on years of experience and keeping up with global trends that have placed the brand as the leader in the market.

b. Brand Imagery: Cats Eye has a very positive image in the market. Cats Eye is well known for its classic and elegant designs. Cats eye is considered as the Pioneer of Men's Wear fashion in Bangladesh.

c. Brand Judgment: Customers of Bangladeshi market hold a very positive opinion towards Cats Eye. Customers are satisfied with its quality regarding the price. The brand is highly dependable and considerable. Cats Eye is even more preferred than other clothing brands often.

d. Brand Feelings: Customers are satisfied with the brand. People wearing a Cats Eye clothing has a very positive feeling. Cats Eye provides security of its products due to its quality. The brand is also 
appreciated by the society. People wearing Cats Eye products actually feel nice inside.

e. Brand Judgment: Customers of Bangladeshi market hold a very positive opinion towards Cats Eye. Customers are satisfied with its quality regarding the price. The brand is highly dependable and considerable. Cats Eye is even more preferred than other clothing brands often.

f. Brand Feelings: Customers are satisfied with the brand. People wearing a Cat's Eye clothing has a very positive feeling. Cats Eye provides security of its products due to its quality. The brand is also appreciated by the society. People wearing Cats Eye products actually feel nice inside.

g. Brand Resonance: Consumers of Cats Eye are sort of loyal to the brand. There are some loyal customers of the brand who always prefers Cats Eye over other brands. Most of the regular customers are also active praising the brand.

\subsection{Marketing Offerings}

Cats Eye market offerings are shaped up for its target groups like men, women, children and youth. Their product line is around ninety to hundred. Cats Eye brought out simple pattern variations in outfits both men and women. Cats Eye focused on colors to bring a festive value on the outfit.
On the other hand, Cats Eye co-brand Monsoon Rain announces formal and casual shirt \& suit for its male customers,

- Women: Western women clothing, White floral print top etc.,

- Man: Exclusive Blazers, T-shirts, Limited edition formal shirt, exclusive cap, Branded tie etc.

- Youth: Various traditional \& western dresses

\subsection{Operational Network Organogram}

After the collection of the products and arrival in the outlets consumers can buy the products from the retailed outlets. This is how the collection and selling of the product goes on. The operations in the outlets are mainly carried by the managers of the outlets. They mainly are responsible to manage the outlet inventories, product sells, customer services, payment collections and personnel management. They supervise the outlet's performance and are directly responsible to report the Chief Cooperative Officer of Retail and Infrastructure for any kind of operation takes place. The Organogram of the operation network of outlets is given below:

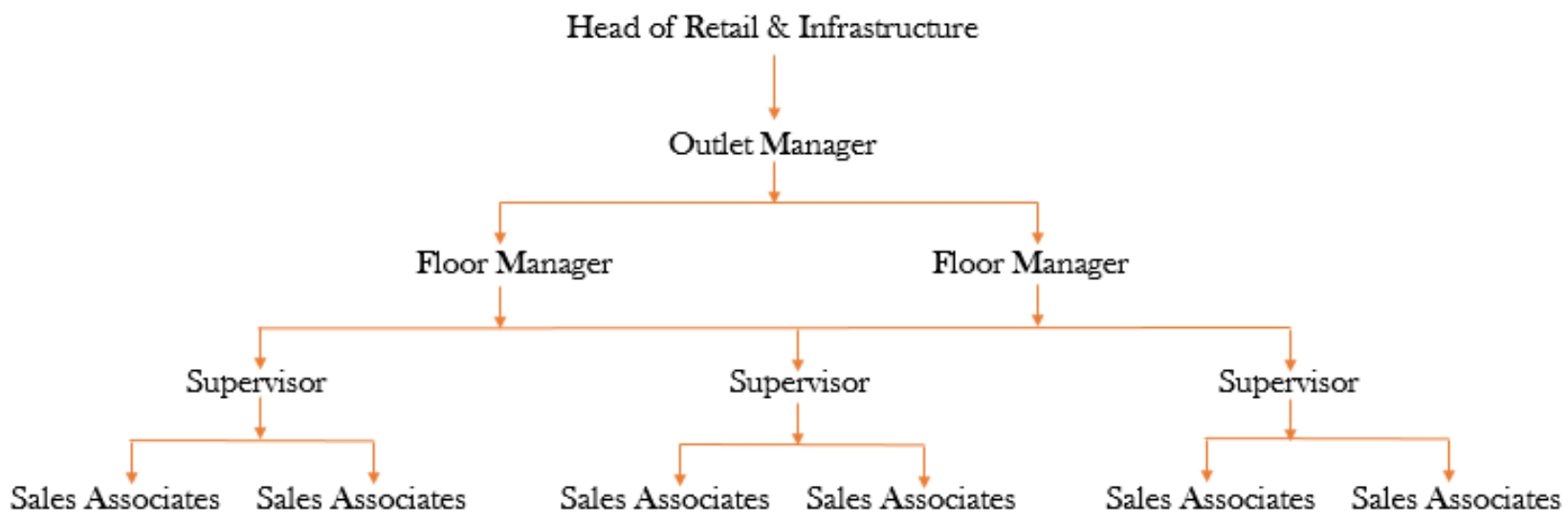

Fig.4: Operational Network Organogram

\subsection{Outlets of Cats Eye}

- The list of Cats Eye outlet is given below:

- New Elephant road Outlet, Dhaka-1205, Rifles

Square Outlet, Dhanmondi , Dhaka,

Bashundhara City Outlet, Panthapath, Dhaka,

Mascot Plaza Outiet, Uttara, Dhaka, Sanmar
Ocean City Outlet , Chittagong, Khulna Outlet, Bogra Outlet 


\begin{tabular}{|c|c|}
\hline Strength & Weakness \\
\hline $\begin{array}{l}\text { Strong branding in the everyday basics, from } \\
\text { casual to work wear etc. } \\
\text { - Well-developed infrastructure } \\
\text { - Consumers trusts the products with their } \\
\text { - } \text { quality } \\
\text { - } \text { Has been in the market for } 10 \text { years } \\
\text { - Experience of long term business } \\
\text { - Advertisement strategy is on point }\end{array}$ & $\begin{array}{l}\text { - Lack of proper marketing strategy } \\
\text { - Less variations in design } \\
\text { - Unable to open shops in all location in } \\
\text { Bangladesh } \\
\text { - Price is high } \\
\text { - Lack of access to key distribution channel }\end{array}$ \\
\hline Opportunities & Threats \\
\hline $\begin{array}{l}\text { - Attracting consumers of various } \\
\text { physiographic segments } \\
\text { - Internationalization of the brand } \\
\text { - Exposure in social media } \\
\text { - Technological advancement } \\
\text { - Development of new products }\end{array}$ & $\begin{array}{l}\text { - Unstable political situation of Bangladesh } \\
\text { - Entry of several foreign famous brands } \\
\text { - Sift in customer tastes } \\
\text { - New regulation }\end{array}$ \\
\hline
\end{tabular}

\subsubsection{Grameen UNIQLO}

\subsection{Overview}

Grameen UNIQLO is a social Business brand of Japan as well as Asia's no. 1 Apparel brand UNIQLO. It's operated as a CSR project of UNIQLO in Bangladesh.

UNIQLO started its operation in Bangladesh as UNIQLO Social Business Bangladesh Ltd. on September 2010.

In 2013 started its first store in Dhaka city in the name of Grameen UNIQLO. Now Grameen UNIQLO has tweleve stores. Grameen UNIQLO is working with the objective of comfortable clothing with affordable price.

\subsection{Mission:}

1. Provide pleasure of wearing exceptional apparel, happiness and satisfaction to all Bangladeshi people.

2. Solve social issues of Bangladesh through business.

3. Reinvest all the profits to promote social business.

\subsection{Key Values \& Features:}

- Unique design by Uniqlo's global expertize

- High quality in affordable price

- Design for comfortability

\subsection{Market Offering}

Products line basically thrusts into Apparels for Men and Women only.
Men's wear: Polo shirt, Business shirt, Casual shirt, Slim fit Chino flat front pant, Slim fit straight jeans, Skinny fit

tapered jeans, Tank top, Boxer, Winter jacket, Sweater , Vest, Cardigan, Parka, Panjabi, Pajama

Women's wear: Kameez Cardigan, Palazzo, Leggings, Pencil pant

\subsection{Outlets:}

- New Elephant Road - 234/2, New Elephant Road (Dr Kudrat e Khuda Road), Dhaka.

- Jamuna Future Park - KA-244, Kuril, Progoti Sharani, Baridhara, Dhaka.

- Mirpur 01 - MM. Islam Plaza, 1-B, Ave, 1-13, Main Road, Kalwala para, Mirpur 01, Dhaka 1216.

- Metro Shopping Mall - Shop-105, Level-01, Metro Shopping Mall, Mirpur Road, Dhanmondi, Dhaka.

- Savar City Centre Store - Shop No -2007-2010 (2nd Floor)Savar City Centre, Savar, Dhaka.

- New Elephant Road (New) - 53/2, (Ground and First Floor) New Elephant Road,New Market,Dhaka-1205.

- Khilgaon Taltola - 566/A, Block C, Taltola, Khilgaon, Dhaka.

- Dhanmondi Science Club - Plot- 28/A Holding \# 01, Road \# 02, Dhanmondi, Dhaka. 
- Naya Paltan - 40/1, D, VIP Road, New Palton, Dhaka.

- Gulshan-Badda link Road - Ja-80, Bir Uttam Ak

Khandaker Sharok, Gulshan Badda Link road,

Dhaka.

4.1.2.5.6 SWOT analysis
- Bashundhara City - Shop- 92 \& 93, Level-2, Block -C,Dhaka.

Table 15: SWOT analysis of Grameen Uniqlo

\begin{tabular}{|c|c|}
\hline Strength & Weakness \\
\hline $\begin{array}{l}\text { - Ascending popularity of the brand } \\
\text { - Good quality product } \\
\text { - Unique features introduced } \\
\text { - Adequate marketing strategy } \\
\text { - Reasonable pricing of the products } \\
\text { - Socially responsible }\end{array}$ & $\begin{array}{l}\text { - Lack of proper marketing strategy } \\
\text { - Less variations in design } \\
\text { - Unable to open shops in all location in } \\
\text { Bangladesh } \\
\text { - Lack of access to key distribution } \\
\text { channel }\end{array}$ \\
\hline Opportunities & Threats \\
\hline $\begin{array}{l}\text { - Attracting consumers of various } \\
\text { physiographic segments } \\
\text { - Exposure in social media } \\
\text { - Technological advancement } \\
\text { - Development of new products } \\
\text { - Different approach to marketing }\end{array}$ & $\begin{array}{l}\text { - Unstable political situation of } \\
\text { Bangladesh } \\
\text { - Entry of several foreign famous brands } \\
\text { - Competitors offering similar products } \\
\text { - New regulation }\end{array}$ \\
\hline
\end{tabular}

\subsection{Data Analysis}

4.2.1 Data analysis of global brands:

4.2.1.1 Analysis of geographical location of global brands:

Table 16: Analysis of geographical location of global brands

\begin{tabular}{|l|l|l|}
\hline Brand's & Number & Percentage (\%) \\
\hline Europe & 5 & 50.00 \\
\hline North America & 3 & 30.00 \\
\hline Oceania & 1 & 10.00 \\
\hline South America & 1 & 10.00 \\
\hline & Total: 8 & \\
\hline
\end{tabular}

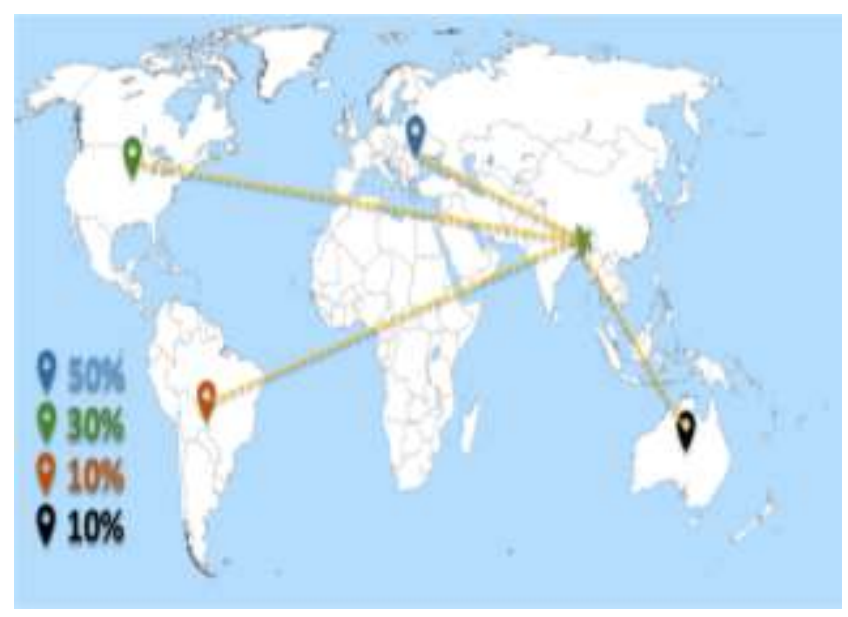

Fig 5: Location of the collected samples of global brands

\subsubsection{Similarities \& Dissimilarities between Global Branded Products:}

After the extraction of data from the tech packs, surveys and researching the respective websites of the related global brands, we have come to these following conclusions:

- Almost all of the products that we have studied are made of high quality cotton fabric. These brands do not compromise quality, comfort and serviceability for their products. This concludes that most of the global brands seek their customer's satisfaction by providing superior quality and comfort.

- Our textile industry is apt to provide the fabric of required quality and features for the global branded knit products. In most of the cases the fabric is sourced locally from Bangladesh and produced in house of the garments manufacturers. 
- Most of accessories are sourced from local market in Bangladesh, and in some cases they are sourced from China.

- In our study, we found some of the brands having versatile products. Selling apparel is only a part of their business. For example: Kmart, Cencosud.

- Some are targeting a particular segment of consumer. For example, Victoria's secret is such kind of a brand, selling only women clothing. Sports Direct sells only sports goods.
- Some brands have varieties of items for all kinds of consumers: Men, Women, and Kids. For example: C\&A, Next.

- All of these brands are highly cautious about the usage of toxic materials during production and also prefer certain certifications and tastes for their products.

- They prefer sustainable products for their customers.

\subsubsection{Data analysis of local brands}

\subsubsection{Information received from the survey:}

Table 17: Data Analysis and Interpretation for Yellow

\begin{tabular}{|l|l|l|l|l|l|}
\hline Particulars & Strongly & Agree & Neutral & Disagree & Strongly \\
\hline 1. Fabrics of Yellow are good. & $65 \%$ & $15 \%$ & $20 \%$ & $0 \%$ & $0 \%$ \\
\hline 2. Products of yellow are comfortable & $55 \%$ & $20 \%$ & $10 \%$ & $15 \%$ & $0 \%$ \\
\hline 3. Yellow should extend its brand and & $30 \%$ & $25 \%$ & $35 \%$ & $10 \%$ & $0 \%$ \\
\hline 4. You are satisfied with the finishing, & $40 \%$ & $30 \%$ & $35 \%$ & $5 \%$ & $0 \%$ \\
\hline 5. The Price of Yellow products are & $5 \%$ & $10 \%$ & $15 \%$ & $60 \%$ & $10 \%$ \\
\hline 6. All lines of products are available in & $30 \%$ & $20 \%$ & $40 \%$ & $10 \%$ & $0 \%$ \\
\hline 7. You purchase Yellow products for & $10 \%$ & $10 \%$ & $60 \%$ & $20 \%$ & $0 \%$ \\
\hline 8. The Promotional activities of Yellow & $10 \%$ & $25 \%$ & $55 \%$ & $10 \%$ & $0 \%$ \\
\hline
\end{tabular}

Table 18: Data Analysis and Interpretation for Aarong

\begin{tabular}{|l|l|l|l|l|l|}
\hline Particulars & Strongly & Agree & Neutral & Disagree & Strongly \\
\hline 1. Fabrics of Aarong are good. & $60 \%$ & $30 \%$ & $10 \%$ & $0 \%$ & $0 \%$ \\
\hline 2. Products of Aarong are comfortable & $65 \%$ & $25 \%$ & $10 \%$ & $0 \%$ & $0 \%$ \\
\hline 3. Aarong should extend its brand and & $5 \%$ & $5 \%$ & $30 \%$ & $50 \%$ & $10 \%$ \\
\hline 4. You are satisfied with the finishing, & $20 \%$ & $5 \%$ & $60 \%$ & $15 \%$ & $0 \%$ \\
\hline 5. The Price of Aarong products are & $5 \%$ & $15 \%$ & $10 \%$ & $60 \%$ & $10 \%$ \\
\hline 6. All lines of products are available in & $10 \%$ & $20 \%$ & $40 \%$ & $20 \%$ & $10 \%$ \\
\hline 7. You purchase Aarong products for & $15 \%$ & $30 \%$ & $25 \%$ & $30 \%$ & $0 \%$ \\
\hline 8. The Promotional activities of Aarong & $20 \%$ & $40 \%$ & $30 \%$ & $10 \%$ & $0 \%$ \\
\hline
\end{tabular}

Table 19: Data Analysis and Interpretation for Ecstasy

\begin{tabular}{|l|l|l|l|l|l|}
\hline Particulars & Strongly & Agree & Neutral & Disagree & Strongly \\
\hline 1. Fabrics of Ecstasy are good. & $5 \%$ & $15 \%$ & $40 \%$ & $25 \%$ & $15 \%$ \\
\hline 2. Products of Ecstasy are comfortable & $5 \%$ & $20 \%$ & $40 \%$ & $25 \%$ & $10 \%$ \\
\hline 3. Ecstasy should extend its brand and & $5 \%$ & $15 \%$ & $50 \%$ & $30 \%$ & $0 \%$ \\
\hline 4. You are satisfied with the finishing, & $5 \%$ & $10 \%$ & $55 \%$ & $15 \%$ & $15 \%$ \\
\hline 5. The Price of Ecstasy products are & $10 \%$ & $30 \%$ & $25 \%$ & $25 \%$ & $10 \%$ \\
\hline 6. All lines of products are available in & $0 \%$ & $10 \%$ & $50 \%$ & $25 \%$ & $15 \%$ \\
\hline 7. You purchase Ecstasy products for & $25 \%$ & $25 \%$ & $20 \%$ & $25 \%$ & $5 \%$ \\
\hline 8. The Promotional activities of Ecstasy & $5 \%$ & $5 \%$ & $50 \%$ & $30 \%$ & $10 \%$ \\
\hline
\end{tabular}

Table 20: Data Analysis and Interpretation for Cats eye 


\begin{tabular}{|l|l|l|l|l|l|}
\hline Particulars & Strongly & Agree & Neutral & Disagree & Strongly \\
\hline 1. Fabrics of Cats eye are good. & $10 \%$ & $20 \%$ & $50 \%$ & $15 \%$ & $5 \%$ \\
\hline 2. Products of Cats eye are comfortable & $5 \%$ & $5 \%$ & $50 \%$ & $25 \%$ & $15 \%$ \\
\hline 3. Cats eye should extend its brand and & $20 \%$ & $35 \%$ & $25 \%$ & $15 \%$ & $5 \%$ \\
\hline 4. You are satisfied with the finishing, & $10 \%$ & $20 \%$ & $60 \%$ & $10 \%$ & $0 \%$ \\
\hline 5. The Price of Cats eye products are & $5 \%$ & $25 \%$ & $40 \%$ & $20 \%$ & $10 \%$ \\
\hline 6. All lines of products are available in & $20 \%$ & $40 \%$ & $30 \%$ & $10 \%$ & $0 \%$ \\
\hline 7. You purchase Cats eye products for & $0 \%$ & $5 \%$ & $55 \%$ & $30 \%$ & $10 \%$ \\
\hline 8. The Promotional activities of Cats eye & $0 \%$ & $5 \%$ & $25 \%$ & $50 \%$ & $20 \%$ \\
\hline
\end{tabular}

Table 21: Data Analysis and Interpretation for Grameen UNIQLO

\begin{tabular}{|l|l|l|l|l|l|}
\hline Particulars & Strongly & Agree & Neutral & Disagree & Strongly \\
\hline 1. Fabrics of Grameen UNIQLO are good. & $5 \%$ & $15 \%$ & $40 \%$ & $25 \%$ & $15 \%$ \\
\hline 2. Products of Grameen UNIQLO are & $10 \%$ & $30 \%$ & $40 \%$ & $20 \%$ & $0 \%$ \\
\hline 3. Grameen UNIQLO should extend its & $20 \%$ & $35 \%$ & $40 \%$ & $5 \%$ & $0 \%$ \\
\hline 4. You are satisfied with the finishing, & $0 \%$ & $5 \%$ & $70 \%$ & $20 \%$ & $5 \%$ \\
\hline 5. The Price of Grameen UNIQLO products & $10 \%$ & $25 \%$ & $40 \%$ & $20 \%$ & $5 \%$ \\
\hline 6. All lines of products are available in & $10 \%$ & $30 \%$ & $30 \%$ & $25 \%$ & $5 \%$ \\
\hline 7. You purchase Grameen UNIQLO & $0 \%$ & $5 \%$ & $70 \%$ & $20 \%$ & $0 \%$ \\
\hline 8. The Promotional activities of Grameen & $0 \%$ & $5 \%$ & $45 \%$ & $35 \%$ & $15 \%$ \\
\hline
\end{tabular}




\section{Representation of data analysis for Yellow}

Fabric Quality

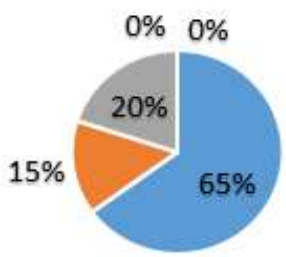

Brand Extension \& the Introduction of New Products
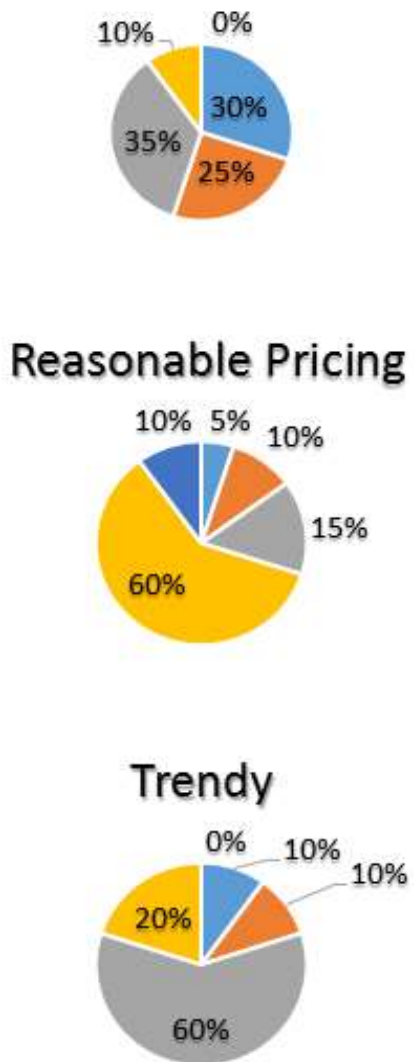

\section{Comfort}

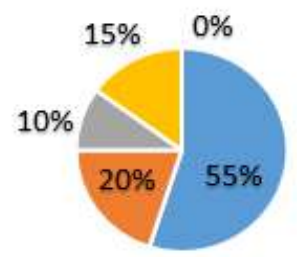

\section{Satisfaction}

$5 \% 0 \%$

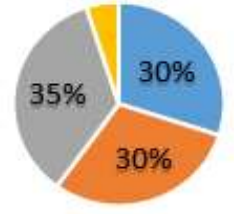

Availability of the Products

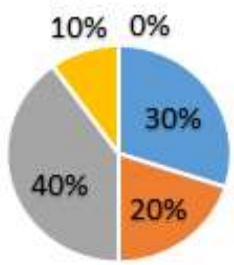

Good Promotional Activities

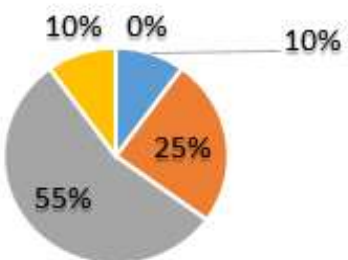

Fig 6: Graphical representation of data analysis of Yellow 


\section{Representation of data analysis for Aarong}
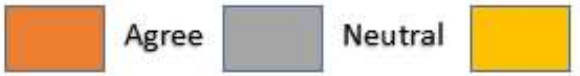

Disagree

Strongly Disagree
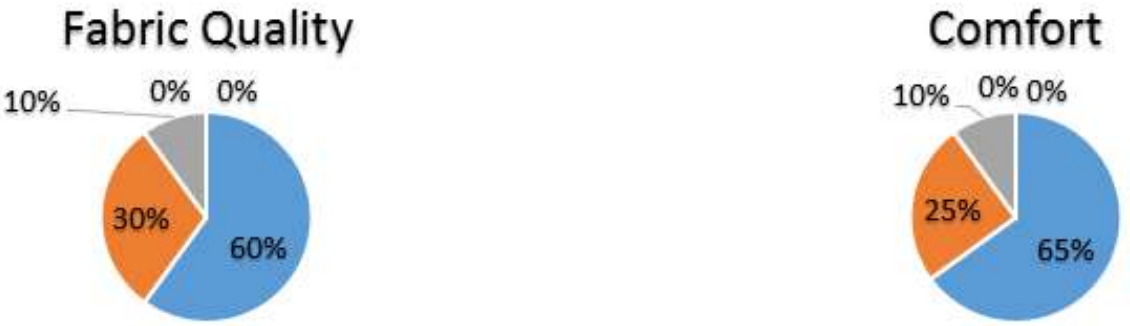

Brand Extension \& the Introduction of New Products
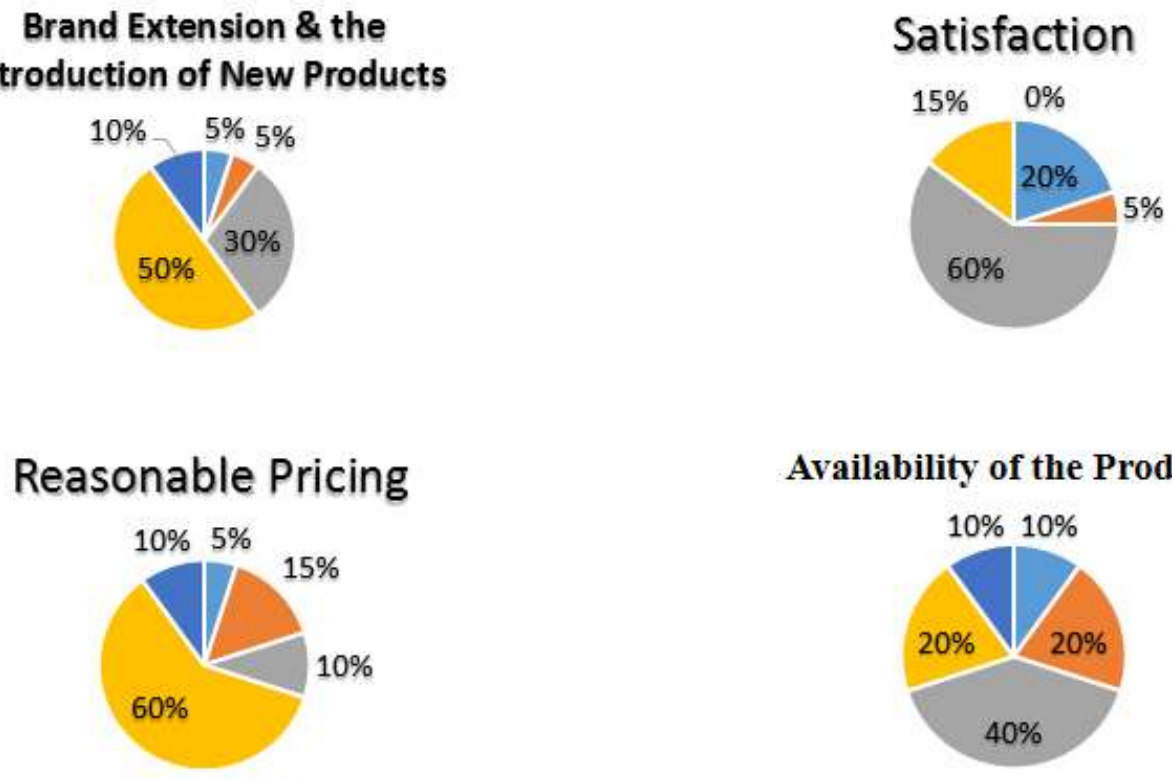

Availability of the Products

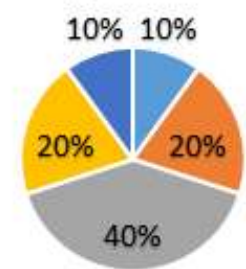

\section{Trendy}

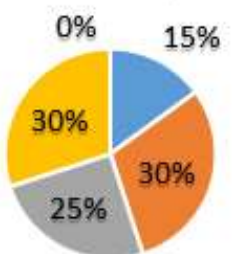

Good Promotional Activities

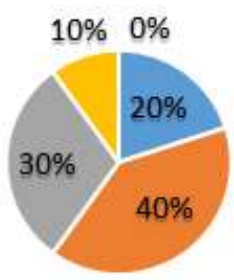

Fig 7: Graphical representation of data analysis of Aarong 


\section{Representation of data analysis for Ecstasy}

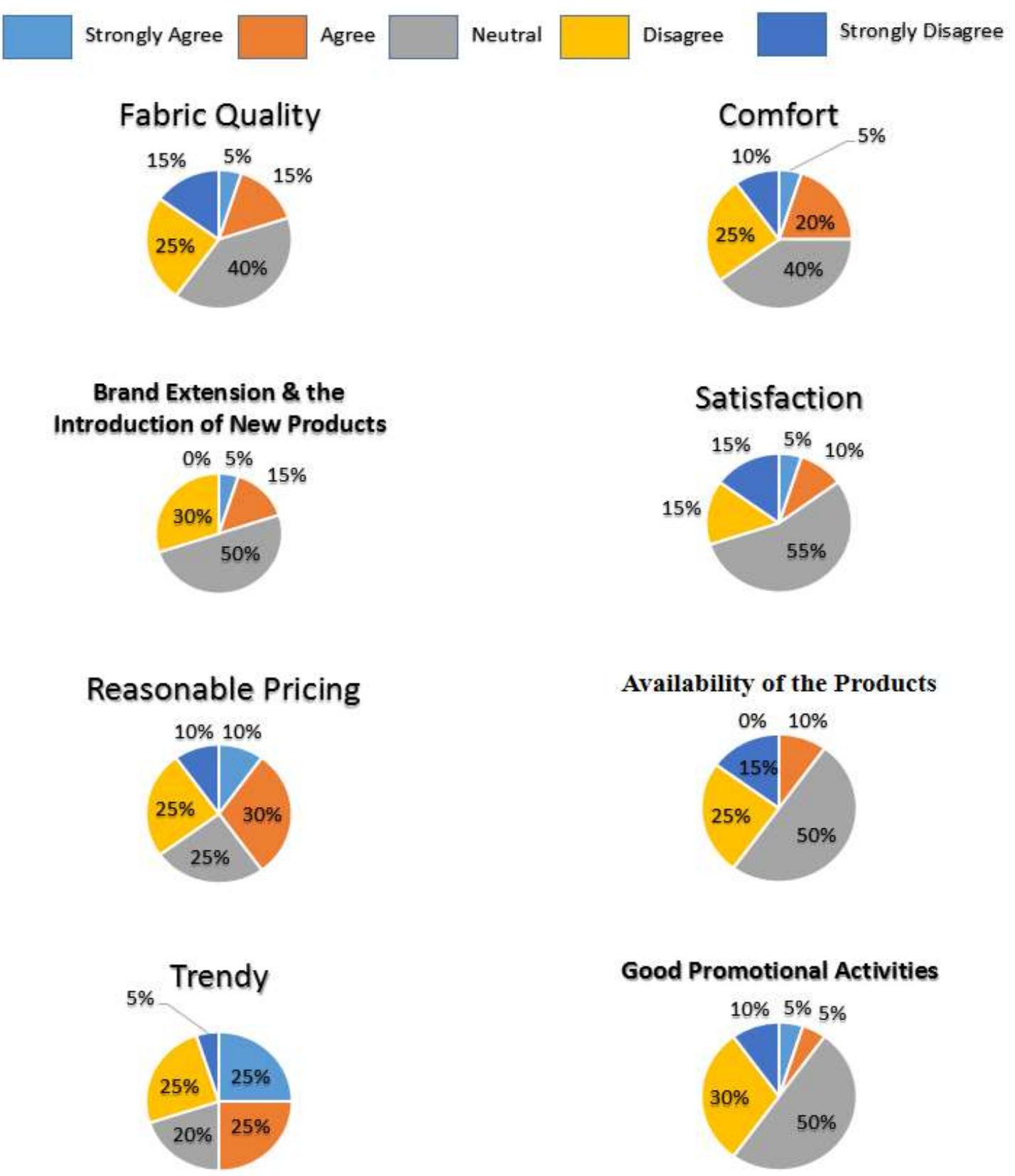

Brand Extension of New Product

Reasonable Pricing

$10 \% 10 \%$

$25 \%$

$25 \%$
Good Promotional Activities

Fig 8: Graphical representation of data analysis of Ecstasy 


\section{Representation of data analysis for Cats eye}
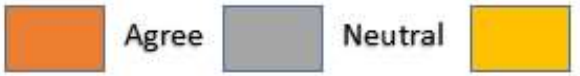

Disagree

Strongly Disagree

\section{Fabric Quality}

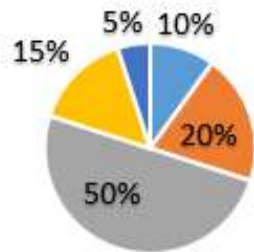

Brand Extension \& the Introduction of New Products

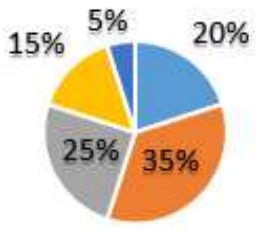

\section{Reasonable Pricing}

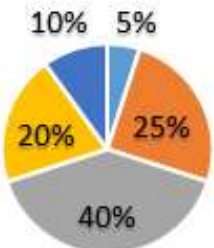

Trendy

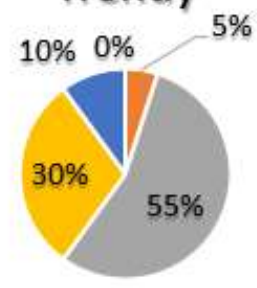

Comfort

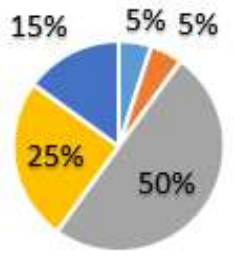

Satisfaction

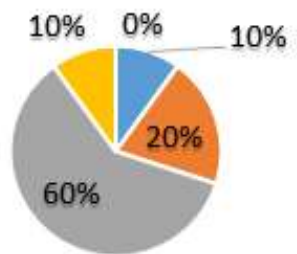

Availability of the Products

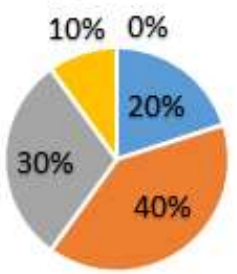

Good Promotional Activities

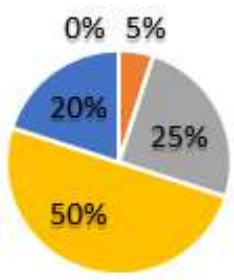

Fig 9: Graphical representation of data analysis of Cats eye 


\section{Representation of data analys is for Grameen UNIQLO}

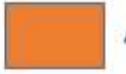

Agree
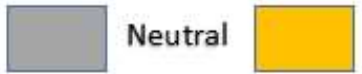

Disagree

Strongly Disagree

\section{Fabric Quality}

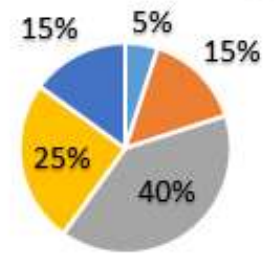

Brand Extension \& the Introduction of New Products

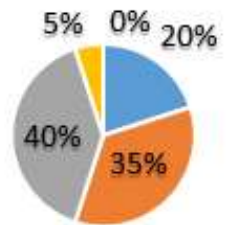

Reasonable Pricing
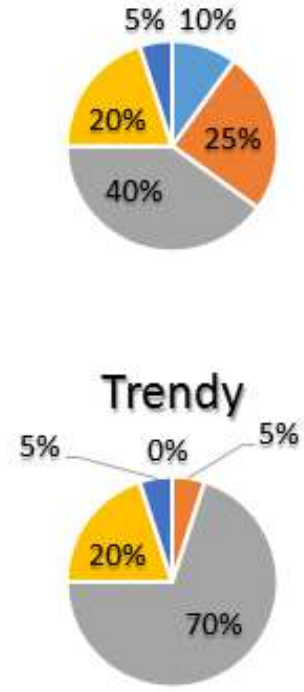

Comfort
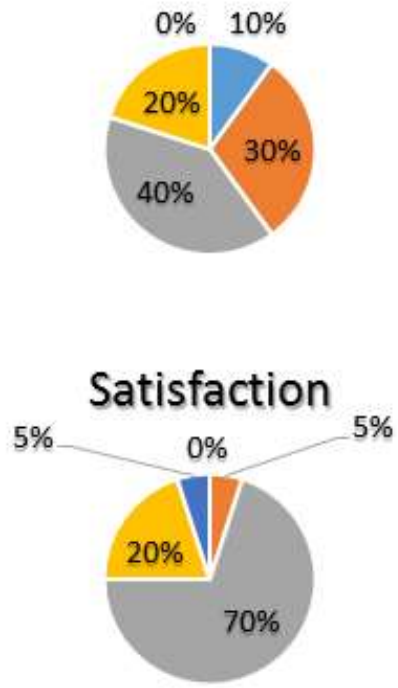

Availability of the Products

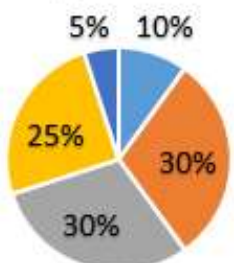

Good Promotional Activities

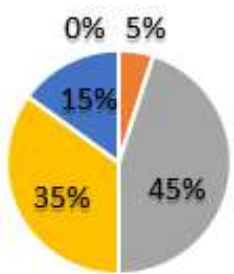

Fig 10: Graphical representation of data analysis of Grameen UNIQLO 
4.2.2.2 Consumer purchase decision

From the survey, the factors which influence the purchase

behavior of a consumer has been charted here to have a better insight on customer psychology.

Table 22: Consumer's purchase decision

\begin{tabular}{|c|c|c|}
\hline Factors & Total Number & Percentage \\
\hline Brand Loyalty & 10 & $12.5 \%$ \\
\hline Quality & 24 & $30 \%$ \\
\hline Price & 22 & $27.5 \%$ \\
\hline Design & 9 & $11.25 \%$ \\
\hline Comfort & 15 & $18.75 \%$ \\
\hline Total & $\mathbf{8 0}$ & \\
\hline
\end{tabular}

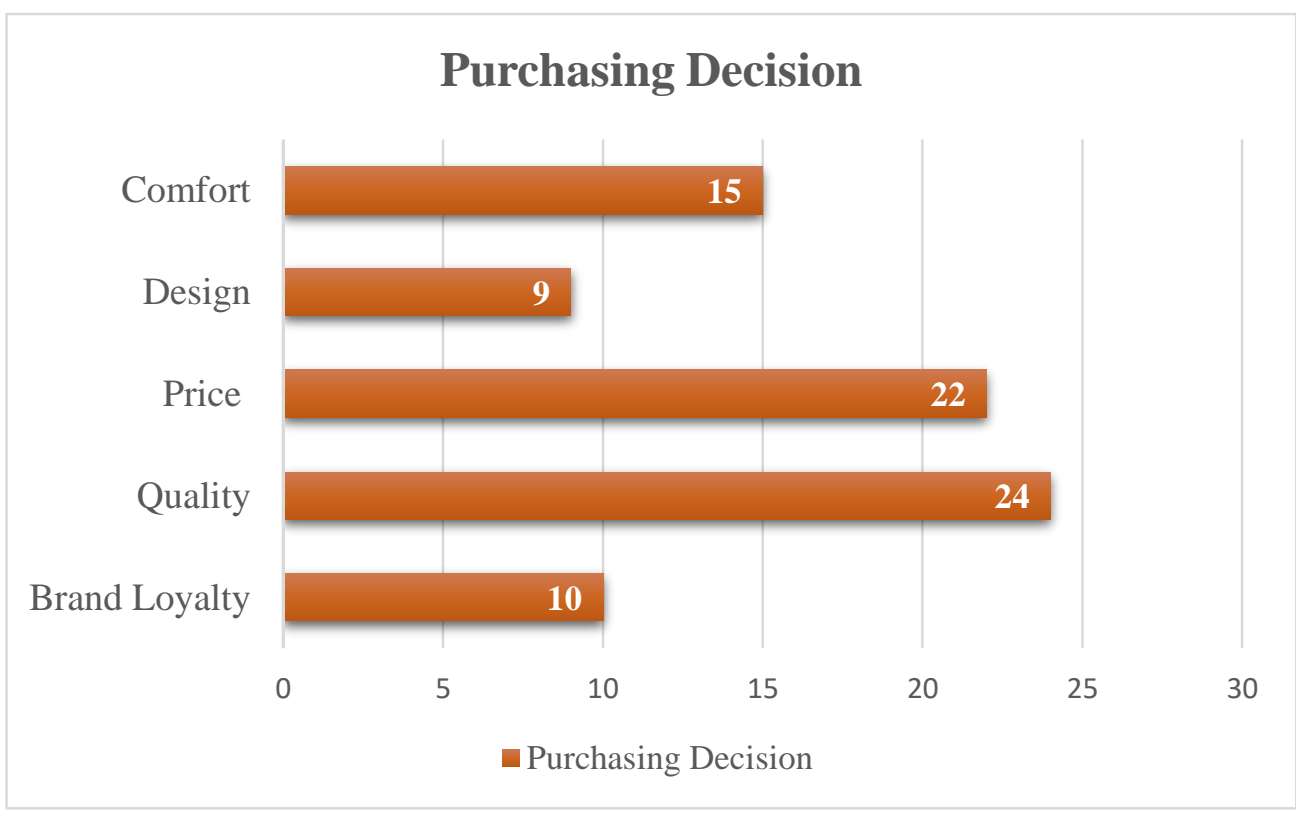

Fig 11: Bar diagram of consumer's purchase decision Purchasing Decision in Percantage

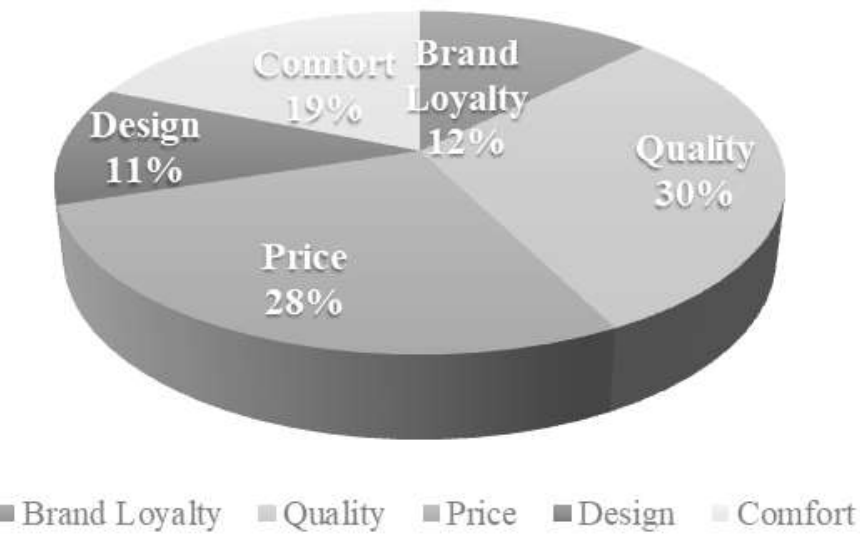

Fig 12: Consumer's purchase decision in percentage 


\section{Conclusion}

5.1 Key findings

* An overview of the global apparel brands who source their products from Bangladesh

* The key features, values and mission at glance.

* The market offerings by the brands.

* The distribution and the store locations of the brands around the world.

* Initiatives towards sustainability.

* Some samples of the products sourced; their materials, costing and other relevant information.

* An overview of the local brands who are the pioneers in Bangladesh's fashion industry.

* The organizational hierarchy of the company.

* Their market offerings of the local brands.

* SWOT analysis of the local brands.

* Consumer's perception towards the products and service of the local brands.

\subsection{Limitations}

* For the collected global brands' samples, the information regarding the products is confidential; thus the authorities were reluctant to share the exact information.

* Sample of all types of products could not be collected.

* The samples are not fully representative of the full population.

\subsection{Recommendation}

* The promotional activities of the brands are very low; Most of these brands use Billboard or magazines for their advertisement. They avoid using most popular methods like- TV advertising, Sponsorship etc. So more involvement should be done on promotional activities.

* The color selection \& raw material selection are taken based of consumer's choice \& comfort ability. For these selection data from consumer choice \& their comment \& recommendation should be taken during designing.

* For clothing size is a major factor, most of these brands sizes and fitness are done randomly, that's why they don't have good appearance when
* wearing.so this point must need to take seriously into account.

* And after all the production process of these brands are not done with serious quality controlling. Most of these apparels quality are too much poor, different faults are very

* The brand value are limited within the region of country and they have a limited target market, because of this low range of market targeting they can't make a popular brand among all the people of market as a result a specific brand is popular to a specific group of people. More product criteria should be added.

* These local brands don't have any popular Brand Ambassadors, whom can present theses brand globally \& enrich their brand value. So Brand ambassadors should be chosen from the global celebrities from our country. (Like- Cricket players)

* Poor fashion \& Designing. More experienced fashion designer should be appointed for the task

* No specific initiatives towards sustainability from the local brands. So local brands should focus on that.

* There is a huge difference between FOB price \& selling price for the global brands. This should be reduced.

* From Bangladesh points of view price of the garments of global brands is a little bit low. Buyers should pay more prices to the supplier.

The study provides an impression and overview of the global brands that sources their knit products from Bangladesh, as well as the local brands of the fashion scene of Bangladesh. This also gives an insight on the source of the materials used for the production of such garments and the costing for the fabric and CMT process. From this study we can see that there are not many variations in the types of products sourced from Bangladesh. This indicates that there is room for diversification of the RMG products to export. As the consumer demand is changing constantly in a rapid pace worldwide, this should be a matter of concern for the authorities involved in the textile industries.

People's perception towards the local knit products available for purchasing in the retail 
shops of the aforementioned local brands has been analyzed and discussed here. This study reflects that there are several constraints in the quality, marketing strategy, supply chain and other factors, which are hindering the evolution of these brands to become compatible to the global quality brands. But there are several promising opportunities in our local market for these brands if they can improve a little. When we discuss the result we have seen some problems, here some problems and some recommendations for solving these problems are given below that might be helpful advice for improving brand value. We had to face some limitations during our research, but there were some imperative discoveries made. Considering all the information and facts, some recommendations have also been made. This study is going to aid any individual who wants to have a general knowledge of the scenario of the global brand's sourcing of knit products from Bangladesh and the situation of the local market for knit apparels.

\section{References}

[1] Giddens A. The Consequences of Modernity: Polity Press; 1990.

[2] Han \&Q. Country-Of-Origin Effects and Their Impact Upon Consumers' Perception of Quality. 1985.

[3] Sheth N\&G. Why We Buy What We Buy: A Theory of Consumption Values. Journal of Business Research (J BUS RES). 1991.
[4] Moor L. The Rise of the Brands. 2007.

[5] Hill B\&. 2012.

[6] http://www.next.co.uk. [Online].

[7] https://www.alexanderjulian.com. [Online].

[8] https://www.c-and-a.com/de/de/shop. [Online].

[9] http://sustainability.c-and-a.com/home/. [Online].

[10] https://www.cencosud.com. [Online].

[11] https://www.victoriassecret.com/. [Online].

[12] http://www.kmart.com/en_us/internationallanding.html. [Online].

[13] https://wikivividly.com/wiki/Kmart. [Online].

[14] www.sainsburys.co.uk/. [Online].

[15] https://www.about.sainsburys.co.uk/makinga-difference/our-sustainability-plan. [Online].

[16] https://www.mandco.com. [Online].

[17] https://cottonon.com/AU/. [Online].

[18] https://www.sportsdirect.com. [Online].

[19] http://www.yellowclothing.net. [Online].

[20] www.aarong.com/. [Online].

[21] http://ecstasybd.com. [Online].

[22] https://www.catseye.com.bd/. [Online].

[23] grameenuniqlo.com.bd/. [Online] 